\title{
Penggunaan Statistik Nonparametrik Dalam Menentukan Determinan Keputusan Konsumen Dalam Membeli dan Mengkonsumsi Berbagai Merek Susu Kemasan: Ditinjau dari Perspektif Popularitas, Kualitas dan Harga
}

\author{
Bayu Kharisma ${ }^{1}$ \\ Departemen Ilmu Ekonomi, Fakultas Ekonomi dan Bisnis, Universitas Padjadjaran \\ Jl. Dipati Ukur No. 35 Bandung, 40132, Indonesia
}

\begin{abstract}
Abstrak
Penelitian ini bertujuan untuk menganalisis persepsi konsumen terhadap popularitas, kualitas dan harga berbagai merek susu dan menentukan determinan keputusan konsumen dalam membeli dan mengkonsumsi berbagai merek susu kemasan yang ditinjau dari perspektif popularitas, kualitas dan harga. Metodologi yang digunakan dalam penelitian ini adalah statistik nonparametrik dengan Responden yang terdiri dari golongan pendapatan menengah keatas, pemilihan golongan menengah ke atas ini berdasarkan kepada pertimbangan bahwa produk susu dalam kemasan termasuk cukup mahal. Hasi penelitian menunjukkan bahwa terdapat 41 merek susu yang menjadi pilihan responden dengan tingkat popularitas, yaitu adalah : (1) Dancow dengan jumlah responden 72 (52,94 \%); (2) Bendera dengan jumlah responden 44 (32,59\%); (3) Indomilk dengan jumlah responden 36 (26,86 $\%)$; (4) Sustagen HP dengan jumlah responden $18(14,40 \%)$ dan Anlene dengan jumlah responden $21(17,95 \%)$ Sebagian besar responden memilih susu Dancow di sebabkan oleh beberapa hal, antara lain kualitas content dari tingkat kandungan gizi dan vitamin serta tingkat kepercayaan konsumen akan kebersihan dan keorisinilan kandungan isi sejak dari proses sampai pendistribusian ditambah dengan jaminan dari produsen Nestle yang telah terkenal diseluruh dunia dengan jaminan mutu dan kualitasnya, ditambah dengan data responden tentang pemilihan susu berkualitas terlihat bahwa 52 responden $(38,52 \%)$ menyatakan bahwa susu Dancow mempunyai kualitas paling baik diantara yang lain.
\end{abstract}

\begin{abstract}
This study aims to analyze consumer perceptions of the popularity, quality and price of various brands of milk and determine the determinants of consumer decisions in buying and consuming various brands of packaging milk from the perspective of popularity, quality and price. The methodology used in this research is nonparametric statistics with respondents consisting of middle to upper income class, the selection of upper middle class is based on the consideration that dairy products in the packaging including quite expensive. The result of research shows that there are 41 brands of milk that the respondents choice with the popularity level, that is: (1) Dancow with the number of respondents 72 (52,94\%); (2) Flag with number of respondents 44 (32,59\%); (3) Indomilk with 36 respondents $(26,86 \%)$; (4) Sustagen HP with the number of respondents 18 $(14.40 \%)$ and Anlene with the number of respondents 21 (17.95\%) Most respondents chose Dancow milk caused by several things, such as quality content of nutrient content levels and vitamins and the level of consumer confidence in the cleanliness and originality of the content from the process until distribution plus the guarantee from Nestle producers that have been famous all over the world with quality and quality assurance, plus the respondents data about the selection of quality milk showed that 52 respondents (38.52\%) states that Dancow milk has the best quality among the others.
\end{abstract}

\footnotetext{
1 * Corresponding author, email address: 1 bayu.kharisma@unpad.ac.id
} 


\section{LATAR BELAKANG}

Tidak seorang pun bisa menyangkal bahwa susu mempunyai manfaat yang sangat besar bagi kehidupan manusia. Minuman ini tidak hanya mutlak dibutuhkan oleh seorang manusia yang baru lahir untuk membentuk sel-sel tubuhnya, tetapi juga masih perlu dikonsumsi oleh manusia dewasa. Dengan demikian dari aspek fisik, susu merupakan salah satu unsur makanan yang berguna bagi pembangunan sumber daya manusia.Di negara mana saja, termasuk Indonesia, program pembangunan bangsa utamanya pengembangan sumber daya manusia, tidak terlepas dari konsumsi susu. Semakin maju sebuah negara, semakin besar pula tingkat konsumsi susu oleh masyarakat.

Dengan banyaknya merek susu kemasan yang beredar dipasaran, ada hal yang menarik untuk dicermati, bahwa masing-masing merek memiliki beberapa atribut dan manfaat yang berbeda antara satu dengan yang lainnya, atribut dan manfaat itu sering digunakan untuk menarik minat/selera konsumen. Selain atribut dan manfaat, harga dari masing-masing merek juga berbeda-beda, semakin lengkap/banyak atribut dan manfaatnya semakin tinggi pula harga dari merek susu tersebut. Dari beberapa merek susu yang beredar dipasaran hanya beberapa merek yang benar-benar mendapat tempat di hati dan benak pikiran konsumen di Indonesia. Memahami perilaku konsumen merupakan hal yang penting karena merupakan dasar dalam mendefinisikan pasar, dimana aktivitas manusia memperlihatkan proses perubahan keinginan manusia terusmenerus dalam rangka memuaskan kebutuhannya.

Memahami perilaku konsumen merupakan elemen penting dalam merencanakan dan mengembangkan strategi pasar karena hampir semua strategi pemasaran mempertimbangkan perilaku konsumen. Semakin banyak memahami tingkah laku konsumen dan pendekatan untuk menganalisis perilakunya, maka semakin banyak kesempatan untuk mengembangkan strategi pemasaran yang berhasil. Demikian pula di dalam hal industri susu kemasan. Menyadari bahwa susu sudah termasuk kedalam kebutuhan pokok (mengingat kadar gizinya yang tinggi), maka mengamati perilaku konsumen terhadap berbagai merek susu yang ada dipasaran merupakan hal yang menarik, terutama bagi para pemasar, yang nantinya mungkin akan terjun langsung ke dalam industri tersebut. Pola konsumsi atau pola belanja konsumen dari pasar tradisional (tradisional market) hingga ke pasar modern (supermarket atau hypermarket) serta tingkat 
harga yang beragam dari merek-merek susu kemasan tersebut akan berpengaruh terhadap proses pengambilan keputusan konsumen dalam mengkonsumsi susu untuk kebutuhan sehari-hari. Dengan demikian, penelitian ini bertujuan untuk :

1. Menganalisis persepsi konsumen terhadap popularitas, kualitas dan harga berbagai merek susu.

2. Menganalisis faktor-faktor yang mempengaruhi keputusan dalam membeli dan mengkonsumsi berbagai merek susu ditinjau dari segi popularitas, kualitas dan harga dari berbagai merek susu tersebut.

\section{LANDASAN TEORITIS}

Dengan semakin majunya teknologi dan semakin banyaknya perusahaan yang bergerak di bidang pangan dan minuman, pada saat ini terdapat berbagai merek susu kemasan yang beredar di pasar, baik di pasar tradisional maupun di pasar modern (supermarket dan hypermarket) dalam bentuk kaleng maupun yang dikemas dalam karton, merek-merek tersebut antara lain : Bendera, Dancow, Indomilk, Sustagen HP, susu Anlene dan lain-lain. Berbagai merek susu yang beredar di pasaran memilki keragaman dalam atribut, manfaat dan harga. Dengan adanya perbedaan-perbedaan tersebut memunculkan beberapa merek susu yang memiliki image yang kuat di benak konsumen. Image yang kuat tersebut menggambarkan keberhasilan positioning produk tersebut.

Semakin baik positioning, maka produk tersebut akan semakin populer (terkenal). Dengan banyaknya perusahaan yang menghasilkan produk susu dalam kemasan, maka terjadi persaingan (competition) diantara produsen atau perusahaan tersebut. Menurut M. Porter persaingan dari segi produsen tersebut dapat digambarkan dengan masing-masing produsen berusaha untuk mengedepankan keunggulan mereka dalam hal atribut, manfaat, sehingga masing-masing merek berusaha menjadi top of mind pada produk susu dalam kemasan. Hal ini menjadi sesuatu yang menarik bagi pemasar, bahwa produk yang populer belum tentu memiliki kulaitas yang baik, atau produk yang populer belum tentu yang harganya paling murah atau paling mahal.

Dalam persaingan pada suatu industri, akan memunculkan merek yang menjadi pemimpin pasar (market leader) dan merek yang menjadi pengikut (follower market) dan 
merek yang menjadi ceruk pasar. Sehingga walaupun produsen tersebut memunculkan produk (dalam hal ini susu dalam kemasan) yang pertama kali, namun jika strategi dalam bidang pemasarannya kurang baik, maka merek tersebut bisa dikalahkan oleh produsen lain yang muncul kemudian dengan mengeluarkan produk yang sama. Secara garis besarnya perilaku konsumen dipengaruhi oleh beberapa faktor seperti:

1. Melalui proses psikologis

2. Adanya pengaruh dari lingkungan yang meliputi kelas sosial, budaya, pengaruh pribadi.

3. Adanya perbedaan dari individu yang antara lain adalah sumber daya konsumen, motivasi keterlibatan konsumen, sikap kepribadian, gaya hidup.

Sedangkan perilaku konsumen sangat ditentukan persepsi terhadap suatu merek atau produk yang akan atau telah dikonsumsi. Secara harfiah persepsi dapat diartikan sebagai proses dimana seseorang memberikan arti terhadap lingkungan yang melibatkan pengorganisasian dan menginterprestasikan sebagai stimuli ke dalam aspek psikologis (Gibson,Ivancevich \& Donelly, 1994). Sedangkan konsumen digambarkan sebagai seorang manusia ekonomis yaitu manusia yang membuat keputusan secara rasional.

Namun manusia memiliki keterbatasan sehingga seringkali tidak dapat memaksimalkan keputusannya dalam mempertimbangkan hubungan harga dengan kualitas barang yang akan atau telah dibeli. Persepsi konsumen sangatlah berperan dalam perilaku konsumen yang berkaitan dengan keputusan pembelian terhadap suatu produk. Pengambilan keputusan oleh konsumen untuk melakukan pembelian suatu produk diawali oleh adanya kesadaran atas pemenuhan kebutuhan dan keinginan yang oleh assael disebut need arousal, kemudian dilanjutkan dengan mencari informasi mengenai produk yang diinginkan, informasi tersebut berupa atribut, manfaat serta harga dari produk tersebut Dari berbagai informasi yang diperoleh konsumen melakukan seleksi atas alternatif-alternatif yang ada. Proses seleksi ini disebut dengan tahap evaluasi informasi. Dengan menggunakan berbagai kriteria yang ada dalam benak konsumen, salah satu merek produk dipilih untuk dibeli. Dengan dibelinya merek produk tertentu, proses evaluasi belum berakhir karena konsumen akan melakukan evaluasi pasca pembelian, proses evaluasi ini akan menentukan apakah konsumen merasa puas atau 
tidak atas keputusan pembeliannya. Seandainya konsumen merasa puas, maka kemungkinan akan melakukan pembelian kembali produk dengan merek tersebut dimasa yang akan datang.

Dalam pemasaran proses pengambilan keputusan oleh konsumen sangatlah menarik untuk dicermati karena dapat dijadikan dasar untuk menyusun strategi pemasaran. Pada umumnya konsumen menginginkan perubahan terhadap produk yang diinginkannya. Ada enam kategori sumber perubahan yang dapat mengubah perilaku konsumen dalam membuat keputusan dalam memilih produk. Enam sumber tersebut adalah :

1. Feeling : konsumen dalam mengambil keputusan untuk memilih tidak lepas dari perasaan yang ia miliki terhadap produk tersebut. Kesukaaan terhadap merek produk yang telah ia kenal memungkinkan sikap loyal konsumen kepada produk tetap tinggi. Tetapi pada suatu kondisi dimana konsumen kecewa dengan produk yang ia sukai, maka konsumen akan mencari merek lain yang lebih sesuai dengan keinginannya

2. Penilaian kepada suatu produk dimungkinkan karena adanya pengaruh dari tinggi rendahnya martabat seseorang, yang dinilai punya nilai lebih apabila dibeli. Kondisi ini memungkikonsumen untuk mengubaha perilakunya dalam membeli sesuatu , maka apabila suatu ketika konsumen menemukan produk baru yang akan menambah citra diri serta akan menaikkan prestigenya ia akan pindah ke produk tersebut.

3. Information : Perubahan perilaku konsumen juga dapat terjadi karena adanya informasi yang tepat sesuai dengan keinginan konsumen, sehingga timbul opini yang positif tentang produk tersebutdan kemudian mempengaruhi konsumen dalam mengambil keputusan.

4. Money : uang merupakan sesuatu yang besar pengaruhnya dalam pengambilan keputusan dalam membeli suatu produk. Perubahan perilaku konsumen erat kaitannya dengan daya beli seseorang, income yang diperoleh dapat menjadi ukuran dalam proses pembuatan keputusan dalam mengubah perilakunya.

5. Goods : Dilihat dari segi produk atau barang yang dipasarkan perilaku konsumen dapat berubah, karena produk itu sendiri bisa berubah sesuai dengan tuntutan pasar, sehingga konsumen yang loyal kepada suatu merek harus mau merubah perilaku 
terhadap produk yang proses terbentuknya image positif atau negatif suatu merek produk di benak konsumen.

Proses terbentuknya image suatu merek di benak konsumen sangatlah dipengaruhi proses psikologis didalam diri konsumen. Didalam proses psikologis terdapat pula proses pengolahan informasi dan pembelajaran yang terjadi di benak konsumen yang melibatkan seluruh persepsi dan sikap yang telah terbentuk sebelumnya terhadap suatu produk yang meliputi atribut, manfaat dan harga. Faktor keterkenalan suatu merek produk memegang peranan penting dalam menentukan persepsi konsumen terhadap suatu merek produk. Atribut dan manfaat dari suatu produk merupakan faktor yang sangat menentukan image suatu produk didalam benak konsumen. Kepercayaan konsumen terhadap obyek, atribut dan manfaat edari suatu produk meliputi :

1. Objek-atribut belief : konsumen percaya bahwa susu memiliki kandungan kandungan gizi yang baik

2. Atribut-benefit belief : Konsumen percaya bahwa kandungan gizi yang baik itu dapat meningkatkan kecerdasan dan kesehatan

3. Objek-benefit belief : Konsumen percaya bahwa dengan mengkonsumsi susu dapat meningkatkan kecerdasan dan kesehatan. (Mowen, 1997)

Selain atribut dan manfaat, faktor harga merupakan faktor yang sangat menentukan persepsi konsumen terhadap suatu produk. Secara umum bahwa harga yang lebih tinggi kurang mempunyai kemungkinan untuk dibeli oleh konsumen, akan tetapi pada beberapa kondisi tertentu konsumen memiliki ekspektasi atas hubungan antara harga dengan kualitas. Dalam rentang harga tertentu mengenai suatu produk, konsumen menungkin mempunyai ekspektasi bahwa harga yang lebih tinggi mencerminkan tingkat kualitas yang baik. Berikut ini merupakan suatu kesimpulan yang berdasarkan atas fakta mengenai hubungan antara harga dengan kualitas, dimana ketika harga digunakan sebagai suatu ciri produk yang berkualitas :

1. konsumen memilki keyakinan dan kepercayaan bahwa pada kondisi tertentu harga dapat menunjukkan kualitas produk

2. perbedaan harga yang besar mempunyai dampak pada perbedaan kualitas daripada perbedaan harga yang relatif lebih kecil. 
3. Harga dapat digunakan sebagai indikator kualitas suatu produk apabila produk tersebut mempunyai merek yang sudah sangat terkenal oleh masyarakat luas atau merek tersebut sudah sangat terkenal .

4. Terjadi perbedaan kualitas yang dirasakan atau yang sebenarnya diantara merekmerek yang ada .

5. Kualitas yang aktual sulit untuk dinilai serta diukur secara obyektif atau melalui nama merek atau citra toko.

6. Adanya identifikasi bahwa karakteristik produk dan harga memiliki dampak terhadap persepsi konsumen terhadap kualitas produk itu sendiri. Artinya bahwa semakin banyak konsumen memperoleh atau menerima informasi mengenai karakteristik produk, kurang mempunyai kemungkinan adanya penggunaaan harga sebagai indikator kualitas, sebaliknya konsumen akan menggunakan harga sebagai indikator kualitas apabila konsumen itu mempunyai informasi yang relatif sedikit mengenai karakteristik produk tersebut. Tetapi apabila konsumen terbiasa dengan suatu nama merek atau telah berpengalaman dengan suatu produk tertentuk, maka faktor harga tidak akan mempengaruhi persepsi terhadap suatu merek produk.

\section{METODE PENELITIAN}

Analisis persepsi konsumen terhadap popularitas, kualitas dan harga dari berbagai merek susu yang beredar dipasaran dilakukan dilingkungan kampus MMA IPB, dan khususnya dillakukan terhadap mahasiswa. Responden dalam penelitian ini terdiri dari peserta mahasiswa MMA IPB dengan golongan pendapatan menengah keatas, pemilihan golongan menengah ke atas ini berdasarkan kepada pertimbangan bahwa produk susu dalam kemasan termasuk cukup mahal. Pengambilan sampel responden dilakukan dengan pengisian kuesioner. Setiap responden yang berjumlah sekitar 141 orang diberikan kuesioner yang berisikan merek-merek susu apa yang anda sering gunakan menggunakan kuesioner yang berbentuk rank order scales. Kemudian kuesioner dibagikan kepada responden kemudian, setelah data dari semua responden terkumpul, ingin diketahui persepsi responden (konsumen) terhadap popularitas, kualitas dan harga dari merekmerek susu tersebut. Untuk mengolah hubungan popularitas, kualitas dan harga dari 
merek-merek susu tersebut maka dilakukan beberapa uji statistik seperti uji chi-square dan uji kontingensi.

\section{Analisis Tabulasi Frekuensi}

Tabulasi frekuensi merupakan suatu tabel yang disusun secara terperinci dan tersendiri yang berisi semua variabel penelitian yang menjadi bahan dasar untuk melakukan penelitian selanjutnya yang bertujuan supaya peneliti atau penulis dapat menggambarkan karateristik sampel penelitian. Tabel frekuensi ini terdiri dari dua kolom dan pada umumnya yang memuat jumlah frekuensi dan persentase untuk setiap kategori. Apabila kategori yang frekuensinya cukup kecil dapat digabungkan ke dalam kelompok yang lebih besar agar tabelnya dapat mudah untuk dimengerti, dianalisis dan juga dipahami.

\section{Uji Chi Square}

Uji chi-square merupakan salah satu jenis teknik statistik non parametrik yang bertujuan untuk memperoleh perbedaan frekuensi yang diharapkan dalam kategorikategori tertentu sebagai akibat dari kesalahan sampling (Lind, Marchal, \& Wathen., 2005). Apabila data penelitian terdiri dari frekuensi-frekuensi dalam kategori yang diskrit, uji chi-square dapat dipergunakan untuk menetapkan signifikasi antara dua kelompok yang independen, dimana hipotesis nol dapat diuji dengan rumus :

$$
\chi^{2}=\sum_{i=1}^{r} \sum_{j=1}^{k} \frac{\left(Q_{i j}-E_{i j}\right)^{2}}{E_{i j}}
$$

Keterangan :

$\mathrm{Q}_{\mathrm{ij}} \quad=$ Jumlah observasi untuk kasus-kasus yang dikategorikan dalam baris $\mathrm{ke}-\mathrm{i}$ dan kolom ke $\mathrm{j}$

$\mathrm{E}_{\mathrm{ij}} \quad=$ Banyaknya kasus yang diharapkan di bawah $\mathrm{H}$ o untuk dikategorikan dalam baris ke $-\mathrm{i}$ dan kolom ke $-\mathrm{j}$

$\mathrm{R}=$ Jumlah Baris

$\mathrm{K} \quad=$ Jumlah Kolom

Hipotesa nol ditolak jika $\chi^{2}$ lebih dari atau sama dengan nilai kritis chi square dari tabel. Dalam bahasan ini, uji chi square diaplikasikan untuk menguji apakah ada hubungan antara variabel independen dengan variabel yang dependen yang diperoleh dari hasil riset konsumen dalam kategori tertentu. 


\section{Uji Kontingensi (uji keeratan)}

Berdasarkan nilai chi-square yang diperoleh dari uji chi-square, dapat diketahui nilai dari koefisien kontingensi. Koefisien Kontingensi ini dapat digunakan untuk menunjukkan hubungan keeratan antara variabel. Nilai Koefisien Kontingensi terletak pada kisaran $0-1$. Untuk mendapatkan nilai koefesien kontingensi dapat dilakukan dengan cara perhitungan rumus sebagai berikut (Lind, Marchal, \& Wathen., 2005):

$$
C=\sqrt{\frac{\chi^{2}}{\chi^{2}+n}}
$$

dimana $\chi^{2}$ adalah nilai chi-square dan banyaknya data yang dinyatakan dalam nilai $\mathrm{N}$. Nilai C yang diperoleh berkisar antara -1 sampai +1 . Semakin besar nilai C yang diperoleh maka semakin kuat hubungan antara variabel-variabel yang diuji.

\section{PEMBAHASAN}

\section{PERSEPSI KONSUMEN TERHADAP PRODUK SUSU}

\section{Identifikasi Merek Susu Yang Paling Populer Sampai Pada Merek Yang Kurang}

\section{Populer}

Hasil penelitian yang dilakukan terhadap 141 responden mahasiswa MMA IPB terdapat 41 merek susu yang menjadi pilihan responden. Hasil penelitian terhadap merek susu yang paling populer sampai pada merek yang kurang populer terlihat pada tabel $1 \mathrm{di}$ bawah ini.

Tabel 1. Persepsi Konsumen Terhadap Popularitas Merek Susu

\begin{tabular}{|c|c|c|c|c|c|c|c|c|c|c|c|c|c|}
\hline \multirow{2}{*}{ No } & \multirow{2}{*}{ Merek Susu } & \multicolumn{2}{|c|}{ POPULER 1} & \multicolumn{2}{|c|}{ POPULER 2} & \multicolumn{2}{|c|}{ POPULER 3} & \multicolumn{2}{|c|}{ POPULER 4} & \multicolumn{2}{|c|}{ POPULER 5} & \multirow{2}{*}{$\begin{array}{c}\text { Indeks } \\
\text { Popularitas }\end{array}$} & \multirow{2}{*}{$\begin{array}{c}\text { pangsa } \\
\text { pasar } \\
(\%)\end{array}$} \\
\hline & & $\Sigma$ & $\%$ & $\Sigma$ & $\%$ & $\sum$ & $\%$ & $\Sigma$ & $\%$ & $\Sigma$ & $\%$ & & \\
\hline 1 & ANDEC & 0 & 0,00 & 0 & 0,00 & 1 & 0,75 & 2 & 1,60 & 5 & 4,27 & 12 & 1 \\
\hline 2 & ANLENE & 4 & 2,94 & 2 & 1,48 & 10 & 7,46 & 14 & 11,20 & 21 & 17,95 & 107 & 5 \\
\hline 3 & $\begin{array}{l}\text { BEAR } \\
\text { BRAND }\end{array}$ & 0 & 0,00 & 0 & 0,00 & 2 & 1,49 & 1 & 0,80 & 2 & 1,71 & 10 & 1 \\
\hline 4 & BEBELAC & 0 & 0,00 & 0 & 0,00 & 0 & 0,00 & 0 & 0,00 & 1 & 0,85 & 1 & 0 \\
\hline 5 & BENDERA & 26 & 19,12 & 44 & 32,59 & 28 & 20,90 & 9 & 7,20 & 9 & 7,69 & 417 & 21 \\
\hline 6 & CALCIMEX & 0 & 0,00 & 0 & 0,00 & 1 & 0,75 & 0 & 0,00 & 0 & 0,00 & 3 & 0 \\
\hline 7 & CAP BUNGA & 0 & 0,00 & 0 & 0,00 & 0 & 0 & 0 & 0,00 & 0 & 0,00 & 0 & 0 \\
\hline 8 & CAP ENAK & 0 & 0,00 & 0 & 0,00 & 0 & 0,00 & 0 & 0,00 & 3 & 2,56 & 3 & 0 \\
\hline 9 & CAP NONA & 0 & 0,00 & 0 & 0,00 & 7 & 5,22 & 13 & 10,40 & 14 & 11,97 & 61 & 3 \\
\hline 10 & CARNATION & 1 & 0,74 & 0 & 0,00 & 0 & 0,00 & 4 & 3,20 & 1 & 0,85 & 14 & 1 \\
\hline
\end{tabular}


Bayu Kharisma. Penggunaan Statistik Nonparametrik Dalam Menentukan Determinan Keputusan ......

\begin{tabular}{|c|c|c|c|c|c|c|c|c|c|c|c|c|c|}
\hline 11 & CHILD KID & 0 & 0,00 & 0 & 0,00 & 1 & 0,75 & 0 & 0,00 & 0 & 0,00 & 3 & 0 \\
\hline 12 & DANCOW & 72 & 52,94 & 30 & 22,22 & 14 & 10,45 & 10 & 8,00 & 2 & 1,71 & 544 & 27 \\
\hline 13 & $\begin{array}{l}\text { DUTCH } \\
\text { LADY }\end{array}$ & 0 & 0,00 & 0 & 0,00 & 0 & 0,00 & 1 & 0,80 & 0 & 0,00 & 2 & 0 \\
\hline 14 & ENERCAL & 0 & 0,00 & 0 & 0,00 & 0 & 0,00 & 1 & 0,80 & 0 & 0,00 & 2 & 0 \\
\hline 15 & ENFAPRO & 0 & 0,00 & 0 & 0,00 & 0 & 0,00 & 3 & 2,40 & 2 & 1,71 & 8 & 0 \\
\hline 16 & ENFAMIL & 0 & 0,00 & 0 & 0 & 0 & 0 & 0 & 0 & 1 & 0,85 & 1 & 0 \\
\hline 17 & FEMAFIT & 0 & 0,00 & 0 & 0,00 & 0 & 0,00 & 0 & 0,00 & 1 & 0,85 & 1 & 0 \\
\hline 18 & INDOMILK & 17 & 12,50 & 35 & 25,93 & 36 & 26,87 & 18 & 14,40 & 7 & 5,98 & 376 & 19 \\
\hline 19 & KLIM & 2 & 1,47 & 0 & 0,00 & 2 & 1,49 & 6 & 4,80 & 5 & 4,27 & 33 & 2 \\
\hline 20 & LACTOGEN & 0 & 0,00 & 0 & 0,00 & 0 & 0,00 & 1 & 0,80 & 0 & 0,00 & 2 & 0 \\
\hline 21 & LACTONA & 1 & 0,74 & 0 & 0,00 & 0 & 0,00 & 0 & 0,00 & 0 & 0,00 & 5 & 0 \\
\hline 22 & MILKMAID & 0 & 0,00 & 0 & 0,00 & 0 & 0,00 & 1 & 0,80 & 0 & 0,00 & 2 & 0 \\
\hline 23 & MILO & 2 & 1,47 & 6 & 4,44 & 6 & 4,48 & 4 & 3,20 & 5 & 4,27 & 65 & 3 \\
\hline 24 & MONY & 0 & 0,00 & 0 & 0,00 & 0 & 0,00 & 0 & 0,00 & 1 & 0,85 & 1 & 0 \\
\hline 25 & MORIMOYA & 0 & 0,00 & 0 & 0,00 & 0 & 0,00 & 0 & 0,00 & 1 & 0,85 & 1 & 0 \\
\hline 26 & NUTRICIA & 0 & 0,00 & 0 & 0,00 & 0 & 0,00 & 1 & 0,80 & 0 & 0,00 & 2 & 0 \\
\hline 27 & NUTRILON & 0 & 0,00 & 0 & 0,00 & 1 & 0,75 & 0 & 0,00 & 0 & 0,00 & 3 & 0 \\
\hline 28 & NUTRIMA & 0 & 0,00 & 0 & 0,00 & 0 & 0,00 & 0 & 0,00 & 0 & 0,00 & 0 & 0 \\
\hline 29 & OVALTINE & 0 & 0,00 & 2 & 1,48 & 3 & 2,24 & 6 & 4,80 & 1 & 0,85 & 30 & 2 \\
\hline 30 & PEDIASURE & 0 & 0,00 & 0 & 0,00 & 1 & 0,75 & 2 & 1,60 & 8 & 6,84 & 15 & 1 \\
\hline 31 & PRENAGEN & 0 & 0,00 & 0 & 0,00 & 1 & 0,75 & 1 & 0,80 & 2 & 1,71 & 7 & 0 \\
\hline 32 & PROCAL & 0 & 0,00 & 0 & 0,00 & 0 & 0,00 & 1 & 0,80 & 1 & 0,85 & 3 & 0 \\
\hline 33 & PROLENE & 0 & 0,00 & 1 & 0,74 & 0 & 0,00 & 0 & 0,00 & 3 & 2,56 & 7 & 0 \\
\hline 34 & PROMIL & 0 & 0,00 & 0 & 0,00 & 1 & 0,75 & 0 & 0,00 & 2 & 1,71 & 5 & 0 \\
\hline 35 & S 26 & 0 & 0,00 & 1 & 0,74 & 0 & 0,00 & 0 & 0,00 & 1 & 0,85 & 5 & 0 \\
\hline 36 & SGM & 0 & 0,00 & 0 & 0,00 & 1 & 0,75 & 3 & 2,40 & 0 & 0,00 & 9 & 0 \\
\hline 37 & STEFIT & 0 & 0,00 & 0 & 0,00 & 0 & 0,00 & 1 & 0,80 & 0 & 0,00 & 2 & 0 \\
\hline 38 & $\begin{array}{l}\text { SUSTAGEN } \\
\text { HP }\end{array}$ & 5 & 3,68 & 13 & 9,63 & 14 & 10,45 & 12 & 9,60 & 12 & 10,26 & 155 & 8 \\
\hline 39 & $\begin{array}{l}\text { TROPICANA } \\
\text { SLIM }\end{array}$ & 2 & 1,47 & 0 & 0,00 & 1 & 0,75 & 1 & 0,80 & 1 & 0,85 & 16 & 1 \\
\hline 40 & ULTRA & 4 & 2,94 & 1 & 0,74 & 3 & 2,24 & 8 & 6,40 & 3 & 2,56 & 52 & 3 \\
\hline \multirow[t]{2}{*}{41} & WRP & 0 & 0,00 & 0 & 0,00 & 0 & 0,00 & 1 & 0,80 & 2 & 1,71 & 4 & 0 \\
\hline & TOTAL & 136 & 100,00 & 135 & 100,00 & 134 & 100,00 & 125 & 100,00 & 117 & 100,00 & 1989 & 100 \\
\hline \multicolumn{14}{|c|}{ Keterangan : } \\
\hline
\end{tabular}

Pada tabel di atas, terlihat bahwa merek susu yang paling populer ke 1 ialah susu Dancow dengan jumlah responden $72(52,94 \%)$, merek susu populer yang ke 2 ialah susu Bendera dengan jumlah responden 44 (32, 59\%), merek susu populer yang ke 3 ialah 
susu Indomilk dengan jumlah responden 36 (26,86\%), merek susu populer yang ke 4 ialah susu Sustagen HP dengan jumlah responden 18 (14,40\%). merek susu yang sangat kurang populer ialah susu Anlene dengan jumlah responden 21 dengan persentase 17,95\%. Yang menjadi pemimpin di pasar (market leader) ialah susu merek Dancow dengan indeks popularitas dengan nilai 544 dengan pangsa pasar sebesar 27\% dan yang menjadi pengikut (follower) ialah susu merek Bendera, susu Indomilk, susu Sustagen HP, susu Anlene dengan masing-masing nilai indeks popularitas dimana susu Bendera dengan nilai 417 dengan pangsa pasar 21\%, susu Indomilk 376 dengan pangsa pasar 19\%, Sustagen HP dengan nilai 155 dengan pangsa pasar 8\%, susu Anlene 107 dengan pangsa pasar $5 \%$.

Strategi Dancow sebagai pemimpin (leader market) didasarkan pada bauran pemasaran, yaitu :

1. Penetapan Posisi Produk

Bagaimana seorang pemimpin pasar dalam hal ini Dancow dapat menetapkan posisi yang tepat yang mewakili hastrat konsumen yang tidak terpenuhi dan memanfaatkan peluang secara agresif, terutama dalam memenuhi brand image konsumen. Sedangkan follower mungkin kurang dapat memanfaatkan peluang tersebut.

2. Keputusan Penetapan Harga

Biasanya leader dapat menyesuaikan kualitas produk dengan harga yang tepat.

3. Strategi periklanan dan promosi

Disinilah kekuatan leader (Dancow) dalam memenangkan persaingan. Penanaman tingkat kepercayaan dalam benak konsumen untuk produk susu lebih kepada promosi. Dari data SWA dari tahun 1999 s/d 2001 terlihat produk yang paling diloyalitaskan dan populer dimata konsumen tahun 1999 adalah Dancow, akan tetapi di tahun 2000 Bendera menjadi yang populer dan ditahun 2001 awal, kembali Dancow menjadi peringkat pertama. Dari paparan SWA diambil kesimpulan bahwa penanaman image melalui promosi ditahun 2001 awal, Dancow memegang peringkat pertama dengan top of mind dengan 48,9\% di dalam benak konsumen dari keseluruhan produk. Bila dibandingkan dengan produk susu lainnya hal, sangat jauh persentasi top of mind. Dengan image "Mamah tambah tinggi" yang dikeluarkan dari mulut seorang anak balita mempengaruhi konsumen ditambah dengan gencarnya iklan di media terutama 
televisi. Ini merupakan objek benefit belief bahwa konsumen percaya bahwa konsumen yang mengkonsumsi Dancow anaknya dapat mempercepat proses pertumbuhan. Pada umumnya pola konsumsi belanja rumah tangga sangat dipengaruhi oleh seorang ibu rumah tangga dan secara psikologis seorang ibu rumah tangga sangat memperhatikan kesehatan anaknya.

\section{Seleksi Saluran Distribusi}

Seorang leader (Dancow) mampu menetapkan saluran distribusi bagus, dapat dilihat kemudahan konsumen dalam mendapatkan produk

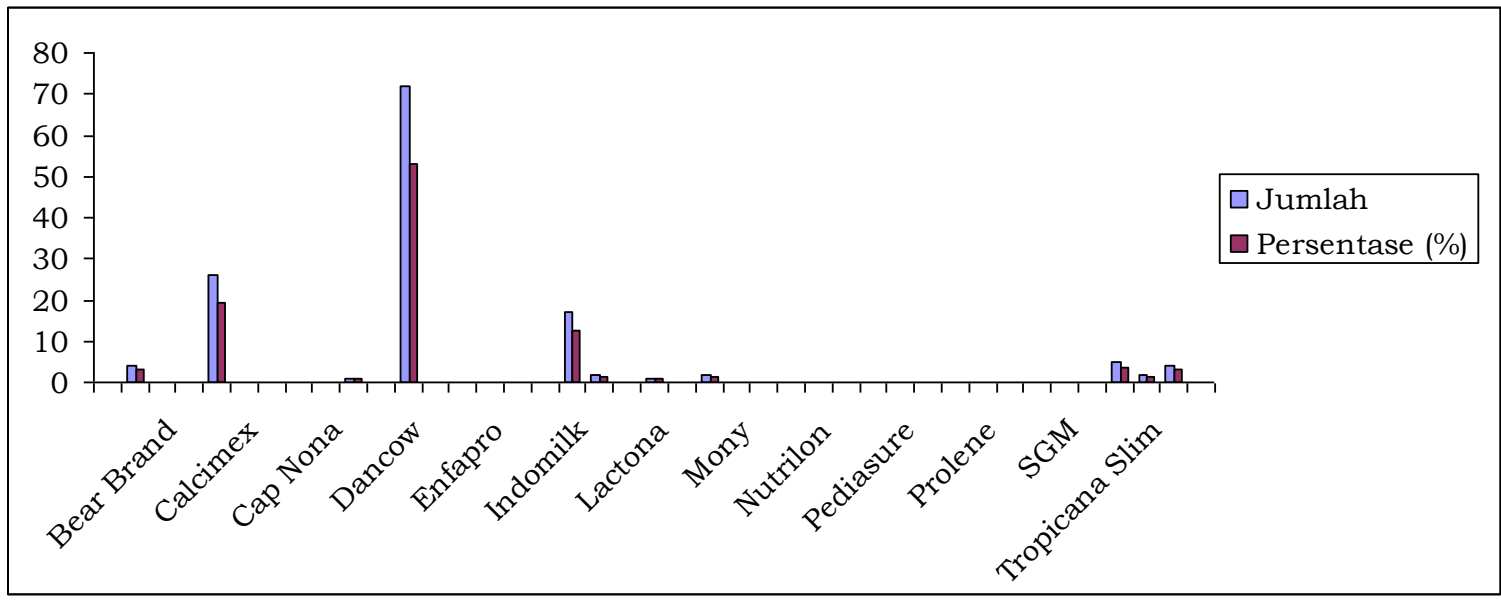

Gambar 1. Persepsi merek susu yang paling populer pertama

\section{Identifikasi Persepsi Kualitas Merek Susu}

Berdasarkan pada data frekuensi mengenai persepsi kualitas berbagai merek susu dapat diperlihatkan pada Tabel 2. Hasil dari 141 responden yang memilih susu yang berkualitas, ternyata 52 responden menganggap bahwa susu Dancow dinyatakan sebagai susu yang memiliki paling baik dibandingkan dengan merek susu yang lainnya dengan atau 38,52\%. Persepsi konsumen tentang kualitas dapat dibentuk dari kepuasan konsumen terhadap merek susu tersebut, persepsi konsumen terhadap manfaat yang didapat dari susu tersebut (product benefit) dan adanya loyalitas terhadap merek produk (Brand loyalty) dan juga adanya frekuensi iklan yang terus menerus-menerus di berbagai media menimbulkan rangsangan (stimulus) yang sangat kuat di dalam benak konsumen.

Tabel 2. Merek Susu Yang Memiliki Kualitas Yang Paling Baik

\begin{tabular}{|c|c|c|c|}
\hline \multirow{2}{*}{ NO } & \multirow{2}{*}{ MEREK SUSU } & \multicolumn{2}{|c|}{ KUALITAS BERBAGAI MEREK SUSU } \\
\cline { 3 - 4 } & & JUMLAH & PERSENTASE $(\%)$ \\
\hline 1 & ANDEC & 1 & 0,74 \\
\hline
\end{tabular}


E-Jurnal Ekonomi dan Bisnis Universitas Udayana 7.4 (2018): 1193-1224

\begin{tabular}{|c|c|c|c|}
\hline 2 & ANLENE & 11 & 8,15 \\
\hline 3 & BEAR BRAND & 0 & 0,00 \\
\hline 4 & BEBELAC & 0 & 0,00 \\
\hline 5 & BENDERA & 8 & 5,93 \\
\hline 6 & CALCIMEX & 1 & 0,74 \\
\hline 7 & CAP BUNGA & 0 & 0,00 \\
\hline 8 & CAP ENAK & 0 & 0,00 \\
\hline 9 & CAP NONA & 1 & 0,74 \\
\hline 10 & CARNATION & 2 & 1,48 \\
\hline 11 & CHILD KID & 0 & 0,00 \\
\hline 12 & DANCOW & 52 & $\mathbf{3 8 , 5 2}$ \\
\hline 13 & DUTCH LADY & 0 & 0,00 \\
\hline 14 & ENERCAL & 0 & 0,00 \\
\hline 15 & ENFAPRO & 0 & 0,00 \\
\hline 16 & ENFAMIL & 1 & 0,74 \\
\hline 17 & FEMAFIT & 1 & 0,74 \\
\hline 18 & INDOMILK & 4 & 2,96 \\
\hline 19 & KLIM & 5 & 3,70 \\
\hline 20 & LACTOGEN & 0 & 0,00 \\
\hline 21 & LACTONA & 1 & 0,74 \\
\hline 22 & MILKMAID & 0 & 0,00 \\
\hline 23 & MILO & 1 & 0,74 \\
\hline 24 & MONY & 0 & 0,00 \\
\hline 25 & MORIMOYA & 0 & 0,00 \\
\hline 26 & NUTRICIA & 0 & 0,00 \\
\hline 27 & NUTRILON & 0 & 0,00 \\
\hline 28 & NUTRIMA & 0 & 0,00 \\
\hline 29 & OVALTINE & 0 & 0,00 \\
\hline 30 & PEDIASURE & 6 & 4,44 \\
\hline 31 & PRENAGEN & 0 & 0,00 \\
\hline 32 & PROCAL & 1 & 0,74 \\
\hline 33 & PROLENE & 2 & 1,48 \\
\hline 34 & PROMIL & 1 & 0,74 \\
\hline 35 & S 26 & 0 & 0,00 \\
\hline 36 & SGM & 0 & 0,00 \\
\hline 37 & STEFIT & 0 & 0,00 \\
\hline 38 & SUSTAGEN HP & 34 & 25,19 \\
\hline 39 & TROPICANA SLIM & 1 & 0,74 \\
\hline 40 & ULTRA & 1 & 0,74 \\
\hline
\end{tabular}




\begin{tabular}{|c|c|c|c|}
\hline 41 & WRP & 0 & 0,00 \\
\hline & TOTAL & 135 & 100,00 \\
\hline
\end{tabular}

Keterangan : 6 Responden tidak memilih

Persepsi tentang kualitas merek susu yang menjadi prioritas responden selain susu Dancow adalah susu Sustagen HP dengan responden yang memilih yaitu 34 responden $(25,19 \%)$, susu Anlene dengan responden yang memlilih yaitu 11 responden $(8,15 \%)$, susu Bendera dengan responden yang memilih yaitu 8 responden $(5,93 \%)$, susu Pediasure dengan responden yang memilih yaitu 6 responden $(4,44 \%)$, susu Klim dengan responden yang memlilih yaitu 5 responden $(3,70 \%)$, susu Indomilk dengan responden yang memilih yaitu 4 responden (2,96\%), susu Prolene dan susu Carnation dengan responden yang memlilih yaitu 2 responden (1,48\%), susu Andec, Calcimex, cap Nona, Enfamil, Femafit, Lactona, Milo, Procal, Promil, Tropicana Slim dan Ultra dengan responden yang memilih sebanyak 1 orang $(0,74 \%)$.



Gambar 2. Persepsi kualitas berbagai merek Susu

\section{Identifikasi Persepsi Harga Berbagai Merek Susu}

Data frekuensi persepsi harga berbagai merek susu dapat terlihat pada tabel 3, dimana terdapat 38 responden $(28,15 \%)$ yang menganggap bahwa susu Sustagen HP memiliki harga yang paling mahal dibandingkan merek susu lainnya. Persepsi konsumen mengenai harga dapat dilihat dari aspek adanya kepercayaan bahwa dalam situasi tertentu harga dapat menunjukkan kualitas dan adanya pengalaman konsumen di dalam membeli produk tersebut serta adanya informasi-informasi dari orang lain atau media informasi lainnya. 
ISSN : 2337-3067

E-Jurnal Ekonomi dan Bisnis Universitas Udayana 7.4 (2018): 1193-1224

Tabel 3. Persepsi Konsumen Mengenai Merek Susu yang Memiliki Harga Paling

\section{Mahal}

\begin{tabular}{|c|c|c|c|}
\hline \multirow{2}{*}{ NO } & \multirow{2}{*}{ MEREK SUSU } & \multicolumn{2}{|c|}{ HARGA BERBAGAI MEREK SUSU } \\
\hline & & JUMLAH & PERSENTASE (\%) \\
\hline 1 & ANDEC & 0 & 0,00 \\
\hline 2 & ANLENE & 23 & 17,04 \\
\hline 3 & BEAR BRAND & 2 & 1,48 \\
\hline 4 & BEBELAC & 0 & 0,00 \\
\hline 5 & BENDERA & 11 & 8,15 \\
\hline 6 & CALCIMEX & 1 & 0,74 \\
\hline 7 & CAP BUNGA & 0 & 0,00 \\
\hline 8 & CAP ENAK & 0 & 0,00 \\
\hline 9 & CAP NONA & 0 & 0,00 \\
\hline 10 & CARNATION & 1 & 0,74 \\
\hline 11 & CHILD KID & 0 & 0,00 \\
\hline 12 & DANCOW & 22 & 16,30 \\
\hline 13 & DUTCH LADY & 0 & 0,00 \\
\hline 14 & ENERCAL & 0 & 0,00 \\
\hline 15 & ENFAPRO & 1 & 0,74 \\
\hline 16 & ENFAMIL & 0 & 0,00 \\
\hline 17 & FEMAFIT & 0 & 0,00 \\
\hline 18 & INDOMILK & 4 & 2,96 \\
\hline 19 & KLIM & 5 & 3,70 \\
\hline 20 & LACTOGEN & 0 & 0,00 \\
\hline 21 & LACTONA & 1 & 0,74 \\
\hline 22 & MILKMAID & 0 & 0,00 \\
\hline 23 & MILO & 3 & 2,22 \\
\hline 24 & MONY & 0 & 0,00 \\
\hline 25 & MORIMOYA & 1 & 0,74 \\
\hline 26 & NUTRICIA & 0 & 0,00 \\
\hline 27 & NUTRILON & 0 & 0,00 \\
\hline 28 & NUTRIMA & 0 & 0,00 \\
\hline 29 & OVALTINE & 1 & 0,74 \\
\hline 30 & PEDIASURE & 9 & 6,67 \\
\hline 31 & PRENAGEN & 1 & 0,74 \\
\hline 32 & PROCAL & 1 & 0,74 \\
\hline 33 & PROLENE & 3 & 2,22 \\
\hline 34 & PROMIL & 1 & 0,74 \\
\hline 35 & S 26 & 2 & 1,48 \\
\hline
\end{tabular}




\begin{tabular}{|c|l|c|c|}
\hline 36 & SGM & 0 & 0,00 \\
\hline 37 & STEFIT & 0 & 0,00 \\
\hline 38 & SUSTAGEN HP & $\mathbf{3 8}$ & $\mathbf{2 8 , 1 5}$ \\
\hline 39 & TROPICANA SLIM & 2 & 1,48 \\
\hline 40 & ULTRA & 1 & 0,74 \\
\hline 41 & WRP & 1 & 0,74 \\
\hline & & 135 & 100,00 \\
\hline
\end{tabular}

Keterangan : 6 Responden tidak memilih

Mengenai persepsi harga, terlihat bahwa sebanyak 23 responden menganggap bahwa susu Anlene memiliki harga paling mahal (17,04\%), susu Dancow 22 responden (16,30\%), susu Bendera 11 responden $(8,15 \%)$, susu Pediasure 9 responden $(6,67 \%)$, susu Klim 5 responden (3,70\%), susu Indomilk 4 responden (2,96\%), yang memilih susu Milo dan Prolene 3 responden (2,22\%), susu Bear Brand, Tropicana Slim dan S 26 dengan 2 responden (2,48\%), susu Calcimex, Carnation, Enfapro, Lactona, Marimoya, Ovaltine, Promil, Ultra dan WRP 1 responden $(0,74 \%)$.

Hasil dari persepsi harga di atas bisa terjadi karena responden tidak memiliki informasi yang jelas mengenai persepsi harga produk susu apabila dikaitkan dengan kualitas susu itu sendiri dan juga bisa disebabkan oleh adanya tidak memiliki gambaran yang jelas dan menyeluruh dari semua merek susu yang ada di pasar baik dilihat dari segi harga atau kualitas.

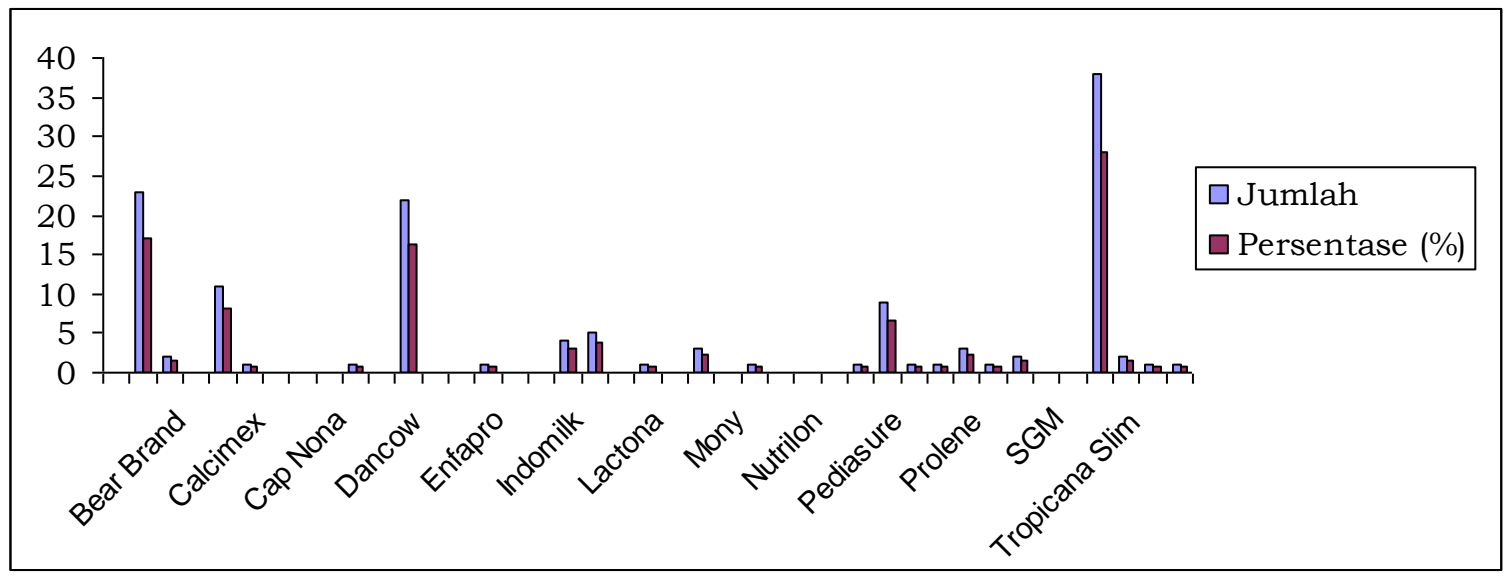

Gambar3 . Persepsi harga berbagai MEREK Susu

\section{Identifikasi Konsumsi Berbagai Merek Susu}

Atas dasar persepsi sebanyak 141 responden dinyatakan bahwa merek susu yang menjadi prioritas ke 1 yang di konsumsi oleh konsumen yaitu susu Dancow dengan 
jumlah 63 responden (46,67\%), merek susu prioritas ke 2 ialah susu Indomilk dengan jumlah responden 29 (23,20\%), merek susu populer ke 3 ialah susu Indomilk dengan jumlah responden 29 (27,36\%). Keberhasilan Dancow menjadi merek susu yang paling banyak dikonsumsi oleh konsumen karena strategi promosi yang ditlakukan oleh Dancow telah berhasil menanamkan positioning yang baik di benak konsumen terutama para ibu rumah tangga.

Tabel 4. Persepsi Konsumen Mengenai Merek Susu Yang Dikonsumsi

\begin{tabular}{|c|c|c|c|c|c|c|c|}
\hline \multirow{2}{*}{ NO } & \multirow{2}{*}{ MEREK SUSU } & \multicolumn{2}{|c|}{ PRIORITAS 1} & \multicolumn{2}{|c|}{ PRIORITAS 2} & \multicolumn{2}{|c|}{ PRIORITAS 3} \\
\hline & & $\sum$ & $\%$ & $\sum$ & $\%$ & $\sum$ & $\%$ \\
\hline 1 & ANDEC & 0 & 0,00 & 3 & 2,40 & 0 & 0,00 \\
\hline 2 & ANLENE & 10 & 7,41 & 5 & 4,00 & 10 & 9,43 \\
\hline 3 & BEAR BRAND & 0 & 0,00 & 1 & 0,80 & 0 & 0,00 \\
\hline 4 & BEBELAC & 0 & 0,00 & 0 & 0,00 & 0 & 0,00 \\
\hline 5 & BENDERA & 25 & 18,52 & 28 & 22,40 & 17 & 16,04 \\
\hline 6 & CALCIMEX & 0 & 0,00 & 1 & 0,80 & 0 & 0,00 \\
\hline 7 & CAP BUNGA & 0 & 0,00 & 0 & 0,00 & 1 & 0,94 \\
\hline 8 & CAP ENAK & 0 & 0,00 & 0 & 0,00 & 0 & 0,00 \\
\hline 9 & CAP NONA & 0 & 0,00 & 1 & 0,80 & 1 & 0,94 \\
\hline 10 & CARNATION & 1 & 0,74 & 0 & 0,00 & 0 & 0,00 \\
\hline 11 & CHILD KID & 0 & 0,00 & 0 & 0,00 & 1 & 0,94 \\
\hline 12 & DANCOW & 63 & 46,67 & 26 & 20,80 & 10 & 9,43 \\
\hline 13 & DUTCH LADY & 0 & 0,00 & 0 & 0,00 & 0 & 0,00 \\
\hline 14 & ENERCAL & 0 & 0,00 & 0 & 0,00 & 1 & 0,94 \\
\hline 15 & ENFAPRO & 0 & 0,00 & 0 & 0,00 & 1 & 0,94 \\
\hline 16 & ENFAMIL & 1 & 0,74 & 0 & 0,00 & 0 & 0,00 \\
\hline 17 & FEMAFIT & 0 & 0,00 & 0 & 0,00 & 0 & 0,00 \\
\hline 18 & INDOMILK & 11 & 8,15 & 29 & 23,20 & 29 & 27,36 \\
\hline 19 & KLIM & 2 & 1,48 & 1 & 0,80 & 3 & 2,83 \\
\hline 20 & LACTOGEN & 0 & 0,00 & 1 & 0,80 & 1 & 0,94 \\
\hline 21 & LACTONA & 0 & 0,00 & 0 & 0,00 & & 0,00 \\
\hline 22 & MILKMAID & 0 & 0,00 & 0 & 0,00 & 1 & 0,94 \\
\hline 23 & MILO & 2 & 1,48 & 5 & 4,00 & 8 & 7,55 \\
\hline 24 & MONY & 1 & 0,74 & 0 & 0,00 & 0 & 0,00 \\
\hline 25 & MORIMOYA & 0 & 0,00 & 0 & 0,00 & 0 & 0,00 \\
\hline 26 & NUTRICIA & 0 & 0,00 & 0 & 0,00 & 0 & 0,00 \\
\hline 27 & NUTRILON & 0 & 0,00 & 0 & 0,00 & 0 & 0,00 \\
\hline 28 & NUTRIMA & 1 & 0,74 & 0 & 0,00 & 0 & 0,00 \\
\hline 29 & OVALTINE & 0 & 0,00 & 1 & 0,80 & 1 & 0,94 \\
\hline
\end{tabular}




\begin{tabular}{|l|l|c|c|c|c|c|c|}
\hline 30 & PEDIASURE & 1 & 0,74 & 5 & 4,00 & 2 & 1,89 \\
\hline 31 & PRENAGEN & 0 & 0,00 & 1 & 0,80 & 1 & 0,94 \\
\hline 32 & PROCAL & 1 & 0,74 & 1 & 0,80 & 1 & 0,94 \\
\hline 33 & PROLENE & 1 & 0,74 & 3 & 2,40 & 0 & 0,00 \\
\hline 34 & PROMIL & 0 & 0,00 & 2 & 1,60 & 0 & 0,00 \\
\hline 35 & S 26 & 0 & 0,00 & 1 & 0,80 & 0 & 0,00 \\
\hline 36 & SGM & 0 & 0,00 & 0 & 0,00 & 1 & 0,94 \\
\hline 37 & STEFIT & 0 & 0,00 & 0 & 0,00 & 0 & 0,00 \\
\hline 38 & SUSTAGEN HP & 12 & 8,89 & 5 & 4,00 & 9 & 8,49 \\
\hline 39 & SROPICANA & 1 & 0,74 & 1 & 0,80 & 2 & 1,89 \\
\hline 40 & ULTRA & 2 & 1,48 & 1 & 0,80 & 5 & 4,72 \\
\hline 41 & WRP & 0 & 0,00 & 3 & 2,40 & 0 & 0,00 \\
\hline & TOTAL & 135 & 100,00 & 125 & 100,00 & 106 & 100,00 \\
\hline
\end{tabular}

Keterangan : $\quad 6$ responden tidak memilih pada merek susu yang dikonsumsi ke 1

16 responden tidak memilih pada merek susu yang dikonsumsi ke 2

35 responden tidak memilih pada merek susu yang dikonsumsi ke 3

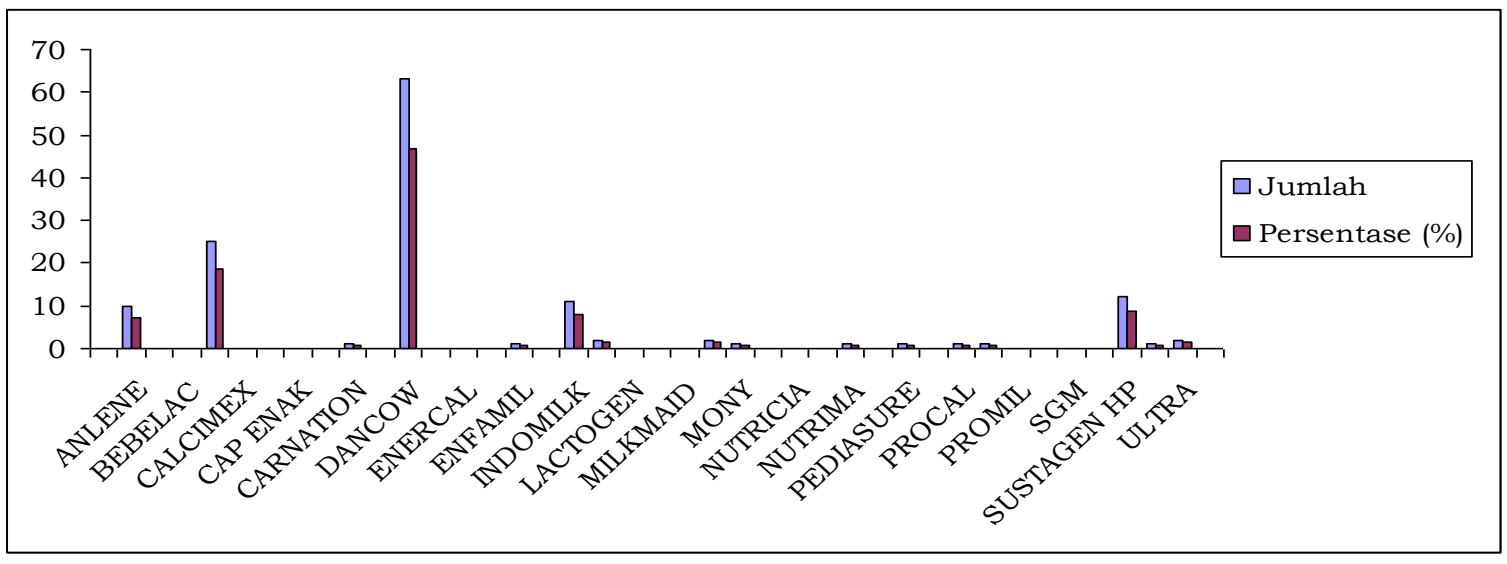

Gambar 4. Persepsi berbagai merek susu yang menjadi prioritas pertama dikonsumsi oleh kosumen.

\section{Identifikasi Rata-Rata Pengeluaran Untuk Membeli Susu Setiap Bulan}

Berdasarkan 141 responden yang diamati, bahwa rata-rata pengeluaran untuk membeli susu setiap bulan dapat diperlihatkan pada tabel 5, dimana sebanyak 22 responden mengeluarkan biaya sebesar Rp. 100.000 untuk membeli susu setiap bulan, 20 responden tidak mengeluarkan biaya untuk membeli susu, 14 responden mengeluarkan biaya sebesar Rp. 200.000 untuk membeli susu setiap bulannya. 12 responden mengeluarkan biaya sebesar Rp. 50.000 untuk membeli susu, 9 responden mengeluarkan biaya sebesar Rp. 150.000 untuk membeli susu, 8 responden mengeluarkan biaya sebesar Rp. 250.000, 6 responden mengeluarkan biaya Rp. 300.000, 4 responden mengeluarkan 
masing-masing biaya sebesar Rp.25.000, Rp. 30.000, Rp. 75.000, 3 responden mengeluarkan biaya yang masing-masing sebesar Rp. 10.000, Rp. 40.000, Rp. 60.000, Rp. 500.000, Rp. Rp. 600.000, 2 responden mengeluarkan biaya yang masing-masing sebesar Rp. 55.000, Rp. 80.000, Rp. 350.000 dan 1 responden masing-masing mengeluarkan biaya masing-masing sebesar Rp. 8.000, Rp. 12.000, Rp. 23.000, Rp. 35.000, Rp. 45.000, Rp. 70.000, Rp. 120.000, Rp. 135.000, Rp. 145.000, Rp. 160.000, Rp. 400.000. Dari keterangan tersebut dapat disimpulkan bahwa dari 141 responden yang mengeluarkan pendapatannya untuk membeli susu, tetapi masih ada yaitu 20 responden $(14,18 \%)$ yang tidak membelanjakan uangnya untuk pembelian susu hal ini bisa disebabkan oleh beberapa faktor yang salah satunya ialah semakin mahalnya harga susu yang disebabkan oleh adanya krisis ekonomi yang terjadi saat ini, sehingga konsumen dalam hal ini cenderung terlebih dahulu untuk mengkonsumsi kebutuhan-kebutuhan pokok selain susu, seperti beras.

Tabel 5. rata-rata pengeluaran untuk membeli susu setiap bulan

\begin{tabular}{|c|c|c|c|}
\hline No & $\begin{array}{c}\text { RATA-RATA PENGELUARAN } \\
\text { UNTUK MEMBELI SUSU SETIAP BULAN }\end{array}$ & JUMLAH & PERSENTASE (\%) \\
\hline 1 & 0 & 20 & 14,18 \\
\hline 2 & 8000 & 1 & 0,71 \\
\hline 3 & 10000 & 3 & 2.13 \\
\hline 4 & 12000 & 1 & 0,71 \\
\hline 5 & 20000 & 5 & 3,55 \\
\hline 6 & 23000 & 1 & 0,71 \\
\hline 7 & 25000 & 4 & 2,84 \\
\hline 8 & 30000 & 4 & 2,84 \\
\hline 9 & 35000 & 1 & 0,71 \\
\hline 10 & 40000 & 3 & 2,13 \\
\hline 11 & 45000 & 1 & 0,71 \\
\hline 12 & 50000 & 12 & 8,51 \\
\hline 13 & 55000 & 2 & 1,42 \\
\hline 14 & 60000 & 3 & 2,13 \\
\hline 15 & 70000 & 1 & 0,71 \\
\hline 16 & 75000 & 4 & 2,84 \\
\hline 17 & 80000 & 2 & 1,42 \\
\hline 18 & 100000 & 22 & 15,60 \\
\hline 19 & 120000 & 1 & 0,71 \\
\hline 20 & 135000 & 1 & 0,71 \\
\hline
\end{tabular}




\begin{tabular}{|l|l|l|l|}
\hline 21 & 145000 & 1 & 0,71 \\
\hline 22 & 150000 & 9 & 6,38 \\
\hline 23 & 160000 & 1 & 0,71 \\
\hline 24 & 200000 & 14 & 9,93 \\
\hline 25 & 250000 & 8 & 5,67 \\
\hline 26 & 300000 & 6 & 4,26 \\
\hline 27 & 350000 & 2 & 0,71 \\
\hline 28 & 400000 & 1 & 2,13 \\
\hline 29 & 500000 & 3 & 2,13 \\
\hline 30 & 600000 & 3 & 0,71 \\
\hline 31 & 1000000 & 1 & \\
\hline
\end{tabular}

ANALISIS HUBUNGAN PERSEPSI POPULARITAS, KUALITAS DAN HARGA

\section{MENGENAI MEREK YANG DIPAKAI RESPONDEN}

\section{Analisa Hubungan Antara Persepsi Popularitas Dengan Kualitas}

Data yang diolah untuk mengetahui hubungan antara popularitas susu dengan kualitas adalah dengan data popularitas susu yang menurut responden paling terkenal dengan data kualitas susu dan pengolahannya dilakukan dengan program Minitab for Windows. Hasil estimasi Minitab tersebut dapat dilihat dalam bentuk tabel dibawah 6 di bawah ini.

Tabel 6. Hubungan Popularitas dengan Kualitas Susu

\begin{tabular}{|c|c|c|c|c|c|c|c|c|c|}
\hline \multirow{2}{*}{\multicolumn{2}{|c|}{ MEREK }} & \multicolumn{7}{|c|}{ KUALITAS SUSU } & \multirow{3}{*}{$\begin{array}{r}\text { Total } \\
4 \\
\end{array}$} \\
\hline & & \multirow{2}{*}{$\begin{array}{c}\text { Anlene } \\
2 \\
\end{array}$} & \multirow{2}{*}{$\begin{array}{c}\text { Bendera } \\
0 \\
\end{array}$} & \multirow{2}{*}{$\begin{array}{c}\text { Dancow } \\
0 \\
\end{array}$} & \multirow{2}{*}{$\begin{array}{c}\text { Pediasure } \\
0\end{array}$} & \multirow{2}{*}{$\begin{array}{c}\text { Sustagen } \\
\text { HP } \\
2 \\
\end{array}$} & \multirow{2}{*}{$\begin{array}{c}\text { Lainnya } \\
0 \\
\end{array}$} & \multirow{2}{*}{$\begin{array}{c}\begin{array}{c}\text { Tidak } \\
\text { Memilih }\end{array} \\
0\end{array}$} & \\
\hline \multirow{7}{*}{  } & Anlene & & & & & & & & \\
\hline & Bendera & 4 & 7 & 5 & 0 & 8 & 1 & 1 & 26 \\
\hline & Dancow & 3 & 1 & 38 & 5 & 13 & 12 & $\mathbf{0}$ & 72 \\
\hline & Indomilk & 2 & 0 & 6 & 0 & 4 & 5 & 0 & 17 \\
\hline & $\begin{array}{l}\text { Sustagen } \\
\text { HP }\end{array}$ & 0 & 0 & 0 & 0 & 5 & 0 & 0 & 5 \\
\hline & Lainnya & 0 & 0 & 3 & 1 & 2 & 5 & 1 & 12 \\
\hline & $\begin{array}{l}\text { Tidak } \\
\text { Memilih }\end{array}$ & 0 & 0 & 0 & 0 & 0 & 1 & 4 & 5 \\
\hline & Total & 11 & 8 & 52 & 4 & 34 & 26 & 6 & 141 \\
\hline
\end{tabular}

Keterangan : $\bullet$ Tidak Memilih (Kosong)

- Kualitas Lainnya (Andec, Bear Brand, Bebelac, Calcimex, Cap Bunga, Cap Enak, Cap Nona, Carnation, Child Kid, Dutch Lady, Enercal, Enfapro, Enfamil, Femavit, Indomilk, Lactogen, Lactona, Milkmaid, Milo, Mony, Morimoya, Nutricia, Nutrilon, Nutrima, Ovaltine, Prenagen, Procal, Prolene, Promil, S 26, SGM, Stefit, Tropicana Slim, Ultra, WRP)

- Populer Lainnya (Andec, Bear Brand, Bebelac, Calcimex, Cap Bunga, Cap Enak, Cap Nona, Carnation, Child Kid, Dutch Lady, Enercal, Enfapro, Enfamil, Femavit, Lactogen, Lactona, Milkmaid, Milo, Mony, Morimoya, Nutricia, Nutrilon, Nutrima, Ovaltine, Pediasure, Prenagen, Procal, Prolene, Promil, S 26, SGM, Stefit, Tropicana Slim, Ultra, WRP) 
- Chi-Square $=139.888$ dan DF $=36$

Hasil Chi-Square yang diperoleh dari hasil pengolahan yang dilakukan oleh Minitab yaitu sebesar 139,888 sedangkan nilai Chi-Square tabel ialah 50,998 pada taraf nyata 5\%, artinya bahwa adanya hubungan antara persepsi popularitas dengan kualitas susu pada tingkat kepercayaan 95\%. Hal tersebut bisa disebabkan oleh gencarnya informasi mengenai produk dari berbagai media baik non visual maupun visual serta adanya ketertarikan konsumen untuk mencoba produk tersebut dan manfaat dari produk tersebut dapat dirasakan dan dibuktikan oleh konsumen. Dari tabel di atas dapat diinterpretasikan bahwa dari 72 responden yang menyatakan bahwa susu Dancow sebagai susu yang paling populer tetapi hanya 38 responden $(52,77 \%)$ yang berpersepsi sebagai susu yang paling populer dan mempunyai kualitas yang paling baik sedangkan 3 responden $(4,17 \%)$ memilih Anlene, 1 responden $(1,38 \%)$ memilih susu bendera, 5 responden $(6,94 \%)$ memilih Pediasure, 13 responden $(18,07 \%)$ memilih Sustagen HP dan memilih susu yang lainnya sebanyak 12 responden $(16,67 \%)$. Kualitas susu tampaknya sangat tergantung pula terhadap tujuan pemakaian dan juga manfaat susu itu sendiri. Misalnya bagi responden yang memandang susu Dancow merupakan susu yang paling berkualitas karena bisa disebabkan oleh manfaat susu tersebut terhadap kesehatan.

\section{Analisis Hubungan Antara Persepsi Popularitas Dengan Harga}

Cross Tabulasi hubungan antara popularitas Susu dengan Harga dapat lihat pada tabel dibawah 7 .

Tabel 7. Hubungan Popularitas dengan Harga Susu

\begin{tabular}{|c|c|c|c|c|c|c|c|c|c|}
\hline \multirow{2}{*}{\multicolumn{2}{|c|}{ MEREK }} & \multicolumn{7}{|c|}{ HARGA SUSU } & \multirow{3}{*}{$\begin{array}{c}\text { Total } \\
4 \\
\end{array}$} \\
\hline & & \multirow{2}{*}{$\begin{array}{c}\text { Anlene } \\
4\end{array}$} & \multirow{2}{*}{$\begin{array}{c}\text { Bendera } \\
0\end{array}$} & \multirow{2}{*}{$\begin{array}{c}\text { Dancow } \\
0\end{array}$} & \multirow{2}{*}{$\begin{array}{c}\text { Pediasure } \\
0\end{array}$} & \multirow{2}{*}{$\begin{array}{c}\text { Sustagen } \\
\text { HP } \\
0\end{array}$} & \multirow{2}{*}{$\begin{array}{c}\text { Lainnya } \\
0\end{array}$} & \multirow{2}{*}{$\begin{array}{c}\begin{array}{c}\text { Tidak } \\
\text { Memilih }\end{array} \\
0\end{array}$} & \\
\hline \multirow{7}{*}{ 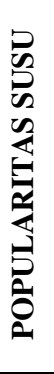 } & Anlene & & & & & & & & \\
\hline & Bendera & 4 & 7 & 3 & 0 & 7 & 4 & 1 & 26 \\
\hline & Dancow & 9 & 3 & 13 & 7 & 21 & 19 & $\mathbf{0}$ & 72 \\
\hline & Indomilk & 4 & 0 & 3 & 1 & 5 & 4 & 0 & 17 \\
\hline & $\begin{array}{l}\text { Sustagen } \\
\text { HP }\end{array}$ & 0 & 0 & 0 & 0 & 5 & 0 & 0 & 5 \\
\hline & Lainnya & 2 & 1 & 3 & 1 & 0 & 4 & 1 & 12 \\
\hline & $\begin{array}{l}\text { Tidak } \\
\text { Memilih }\end{array}$ & 0 & 0 & 0 & 0 & 0 & 1 & 4 & 5 \\
\hline & Total & 23 & 11 & 22 & 9 & 38 & 32 & 6 & 141 \\
\hline
\end{tabular}


- Harga Lainnya (Andec, Bear Brand, Bebelac, Calcimex, Cap Bunga, Cap Enak, Cap Nona, Carnation, Child Kid, Dutch Lady, Enercal, Enfapro, Enfamil, Femavit, Indomilk, Lactogen, Lactona, Milkmaid, Milo, Mony, Morimoya, Nutricia, Nutrilon, Nutrima, Ovaltine, Prenagen, Procal, Prolene, Promil, S 26, SGM, Stefit, Tropicana Slim, Ultra, WRP)

- Populer Lainnya (Andec, Bear Brand, Bebelac, Calcimex, Cap Bunga, Cap Enak, Cap Nona, Carnation, Child Kid, Dutch Lady, Enercal, Enfapro, Enfamil, Femavit, Lactogen, Lactona, Milkmaid, Milo, Mony, Morimoya, Nutricia, Nutrilon, Nutrima, Ovaltine, Pediasure, Prenagen, Procal, Prolene, Promil, S 26, SGM, Stefit, Tropicana Slim, Ultra, WRP)

- Chi-Square $=134,682$ dan DF $=36$

Hasil nilai Chi-Square dari perhitungan ialah 134,582 sedangkan nilai Chi-Square tabel ialah 50,998 pada taraf nyata 5\%, jadi adanya hubungan antara persepsi popularitas dengan persepsi harga susu pada tingkat kepercayaan 95\%. Dapat dikatakan bahwa konsumen mempunyai persepsi bahwa susu yang terkenal dipersepsikan sebagai susu yang harganya mahal, hal ini bisa disebabkan oleh seringnya responden mendapatkan informasi produk baik melalui iklan di media elektronik atau media cetak dan juga media lainnya. Dari tabel di atas dapat diinterpretasikan bahwa dari 72 responden yang menyatakan bahwa susu Dancow sebagai susu yang paling populer tetapi hanya 13 responden $(18,06 \%)$ yang berpersepsi sebagai susu yang paling populer dan mempunyai harga paling mahal sedangkan 9 responden (12,5\%) memilih Anlene, 3 responden $(4,17 \%)$ memilih susu Bendera, 7 responden (9,72\%) memilih Pediasure, 21 responden $(29,17 \%)$ memilih Sustagen HP dan memilih susu yang lainnya sebanyak 19 responden $(26,39 \%)$.

\section{Analisa Hubungan Antara Persepsi Popularitas Dengan Produk Susu Yang Paling Sering Dikonsumsi}

Informasi kaitan antara popularitas dengan susu yang sering dipakai sangat penting sekali untuk diketahui karena berhubungan erat dengan masalah pembelian susu. Tabelnya dapat dilihat pada tabel dibawah ini.

Dari tabel tersebut dapat diinterpretasikan bahwa dari 72 responden yang menyatakan bahwa susu Dancow sebagai susu yang paling populer tetapi hanya 53 responden $(73,01 \%)$ yang berpersepsi sebagai susu yang paling populer dan mempengaruhi pemakaian terhadap susu tersebut, sedangkan 4 responden $(5,56 \%)$ memilih Anlene, 6 responden (8,33\%) memilih susu Bendera, 2 responden $(2,78 \%)$ memilih Indomilk, 3 responden (4,17\%) memilih Sustagen HP dan memilih susu yang lainnya sebanyak 3 responden $(4,17 \%)$ sedangkan 1 responden $(1,39 \%)$ tidak memilih. 
Tabel 8. Hubungan Popularitas Dengan Susu Yang Paling Sering Dikonsumsi

\begin{tabular}{|c|c|c|c|c|c|c|c|c|c|}
\hline \multirow{2}{*}{\multicolumn{2}{|c|}{ MEREK }} & \multicolumn{7}{|c|}{ SUSU YANG DI KONSUMSI } & \multirow{3}{*}{$\begin{array}{r}\text { Total } \\
4\end{array}$} \\
\hline & & \multirow{2}{*}{$\begin{array}{c}\text { Anlene } \\
2 \\
\end{array}$} & \multirow{2}{*}{$\frac{\text { Bendera }}{0}$} & \multirow{2}{*}{$\begin{array}{c}\text { Dancow } \\
0 \\
\end{array}$} & \multirow{2}{*}{$\begin{array}{c}\text { Indomilk } \\
0 \\
\end{array}$} & \multirow{2}{*}{$\begin{array}{c}\text { Sustagen } \\
\text { HP }\end{array}$} & \multirow{2}{*}{$\begin{array}{c}\text { Lainnya } \\
0\end{array}$} & \multirow{2}{*}{$\begin{array}{c}\text { Tidak } \\
\text { Memilih }\end{array}$} & \\
\hline \multirow{7}{*}{ 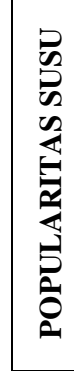 } & Anlene & & & & & & & & \\
\hline & Bendera & 2 & 13 & 5 & 1 & 3 & 2 & 0 & 26 \\
\hline & Dancow & 4 & 6 & 53 & 2 & 3 & 3 & 1 & 72 \\
\hline & Indomilk & 1 & 2 & 2 & 8 & 0 & 4 & 0 & 17 \\
\hline & $\begin{array}{l}\text { Sustagen } \\
\text { HP }\end{array}$ & 0 & 2 & 1 & 0 & 2 & 0 & 0 & 5 \\
\hline & Lainnya & 1 & 2 & 2 & 0 & 2 & 4 & 1 & 12 \\
\hline & \begin{tabular}{|l|} 
Tidak \\
Memilih \\
\end{tabular} & 0 & 0 & 0 & 0 & 0 & 1 & 4 & 5 \\
\hline & Total & 10 & 25 & 63 & 11 & 12 & 14 & 6 & 141 \\
\hline \multicolumn{2}{|c|}{ Keterangan : } & \multicolumn{8}{|c|}{$\begin{array}{l}\text { Tidak Memilih (Kosong) } \\
\text { Konsumsi Lainnya (Andec, Bear Brand, Bebelac, Calcimex, Cap Bunga, Cap Enak, Cap } \\
\text { Nona, Carnation, Child Kid, Dutch Lady, Enercal, Enfapro, Enfamil, Femavit, Lactogen, } \\
\text { Lactona, Milkmaid, Milo, Mony, Morimoya, Nutricia, Nutrilon, Nutrima, Ovaltine, Pediasure, } \\
\text { Prenagen, Procal, Prolene, Promil, S 26, SGM, Stefit, Tropicana Slim, Ultra, WRP) } \\
\text { Populer Lainnya (Andec, Bear Brand, Bebelac, Calcimex, Cap Bunga, Cap Enak, Cap Nona, } \\
\text { Carnation, Child Kid, Dutch Lady, Enercal, Enfapro, Enfamil, Femavit, Lactogen, Lactona, } \\
\text { Milkmaid, Milo, Mony, Morimoya, Nutricia, Nutrilon, Nutrima, Ovaltine, Pediasure, } \\
\text { Prenagen, Procal, Prolene, Promil, S 26, SGM, Stefit, Tropicana Slim, Ultra, WRP) } \\
\text { Chi-Square = 204,075 dan DF = } 36\end{array}$} \\
\hline
\end{tabular}

Hasil nilai Chi-Square dari perhitungan ialah 204,075 sedangkan nilai Chi-Square tabel ialah 50,998 pada taraf nyata 5\% jadi adanya hubungan yang signifikan antara persepsi popularitas dengan persepsi susu yang sering dikonsumsi. Dapat dikatakan bahwa konsumen mempunyai persepsi bahwa susu yang paling populer mempengaruhi pola konsumsi susu atau mempengaruhi merek susu yang dipakai, hal ini bisa disebabkan oleh seringnya responden mendapatkan informasi produk baik melalui iklan di media elektronik atau media cetak dan juga media lainnya.

\section{Analisa Hubungan Antara Persepsi Kualitas Merek Susu yang Baik Dengan Produk Susu yang Mahal}

Dari tabulasi hubungan kualitas dengan harga susu dapat diperlihatkan pada tabel di bawah ini yang pengolahannya dilaukan dengan Mintab for Windows. Pada tabel 9 dapat diperlihatkan bahwa dari 52 responden yang menyatakan bahwa susu Dancow sebagai susu yang paling berkualitas tetapi hanya 19 responden $(36,54 \%)$ yang berpersepsi sebagai susu yang paling berkualitas dan mempunyai harga paling mahal 
sedangkan 7 responden $(13,36 \%)$ memilih Sustagen HP, 6 responden $(11,54 \%)$ memilih Anlene, 4 responden $(7,69 \%)$ memilih susu Bendera, 2 responden (3,85\%) memilih Pediasure dan memilih susu yang lainnya sebanyak 14 responden $(26,92 \%)$.

Tabel 9. Hubungan Kulitas dengan Harga Susu yang Paling Mahal

\begin{tabular}{|c|c|c|c|c|c|c|c|c|c|}
\hline \multirow{2}{*}{\multicolumn{2}{|c|}{ MEREK }} & \multicolumn{7}{|c|}{ HARGA SUSU } & \multirow{2}{*}{ Total } \\
\hline & & Anlene & Bendera & Dancow & Pediasure & $\begin{array}{c}\text { Sustagen } \\
\text { HP }\end{array}$ & Lainnya & $\begin{array}{c}\text { Tidak } \\
\text { Memilih }\end{array}$ & \\
\hline \multirow{7}{*}{ 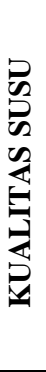 } & Anlene & 9 & 0 & 0 & 0 & 1 & 1 & 0 & 11 \\
\hline & Bendera & 1 & 5 & 1 & 0 & 0 & 1 & 0 & 8 \\
\hline & Dancow & 6 & 4 & 19 & 2 & 7 & 14 & $\mathbf{0}$ & 52 \\
\hline & Pediasure & 0 & 0 & 0 & 6 & 0 & 0 & 0 & 6 \\
\hline & $\begin{array}{l}\text { Sustagen } \\
\text { HP }\end{array}$ & 6 & 0 & 0 & 1 & 26 & 1 & 0 & 34 \\
\hline & Lainnya & 1 & 2 & 2 & 0 & 4 & 15 & 0 & 24 \\
\hline & $\begin{array}{l}\text { Tidak } \\
\text { Memilih } \\
\end{array}$ & 0 & 0 & 0 & 0 & 0 & 0 & 6 & 6 \\
\hline & Total & 23 & 11 & 22 & 9 & 38 & 32 & 6 & 141 \\
\hline
\end{tabular}

Keterangan: $\quad \vee$ Tidak Memilih (Kosong)

- Harga Lainnya (Andec, Bear Brand, Bebelac, Calcimex, Cap Bunga, Cap Enak, Cap Nona, Carnation, Child Kid, Dutch Lady, Enercal, Enfapro, Enfamil, Femavit, Indomilk, Lactogen, Lactona, Milkmaid, Milo, Mony, Morimoya, Nutricia, Nutrilon, Nutrima, Ovaltine, Prenagen, Procal, Prolene, Promil, S 26, SGM, Stefit, Tropicana Slim, Ultra, WRP)

- Kualitas Lainnya (Andec, Bear Brand, Bebelac, Calcimex, Cap Bunga, Cap Enak, Cap Nona, Carnation, Child Kid, Dutch Lady, Enercal, Enfapro, Enfamil, Femavit, Indomilk, Lactogen, Lactona, Milkmaid, Milo, Mony, Morimoya, Nutricia, Nutrilon, Nutrima, Ovaltine, Prenagen, Procal, Prolene, Promil, S 26, SGM, Stefit, Tropicana Slim, Ultra, WRP)

- Chi-Square $=384,145$ dan $\mathrm{DF}=36$

Hasil Chi-Square dari perhitungan ialah 384,145 sedangkan nilai Chi-Square tabel ialah 50,998 pada taraf nyata 5\%, jadi adanya hubungan yang signifikan antara persepsi kualitas dengan persepsi harga susu. Dapat dikatakan bahwa konsumen mempunyai persepsi bahwa kualitas susu dipersepsikan sebagai susu yang harganya mahal, hal ini bisa disebabkan oleh seringnya responden mendapatkan informasi produk baik melalui iklan di media elektronik atau media cetak dan juga media lainnya sepertinya responden bisa membuat seleksi berdasarkan informasi yang ada meskipun semua produk yang dipromosikan melalui iklan menyatakan lebih unggul dari yang lain..

\section{Analisis Hubungan Antara Persepsi Kualitas Merek Susu Dengan Merek Susu Yang Dikonsumsi}

Data persepsi hubungan kualitas merek susu dengan merek susu yang dikonsumsi dapat diperlihatkan pada tabel 10. Dari tabel tersebut dapat diinterpretasikan bahwa dari 
52 responden yang menyatakan bahwa susu Doncow sebagai susu yang paling berkualitas tetapi hanya 40 responden $(76,92 \%)$ yang berpersepsi sebagai susu yang paling sering berkualitas dan mempengaruhi pemakaian terhadap susu tersebut, sedangkan 5 responden $(9,62 \%)$ memilih Indomilk, 2 responden $(3,85 \%)$ memilih susu Bendera, 1 responden $(1,92 \%)$ memilih Sustagen HP, sedangkan 4 responden $(7,69 \%)$ memilih susu lainnya.

Tabel 10. Hubungan Kulitas Merek Susu Dengan Merek Susu Yang Dikonsumsi

\begin{tabular}{|c|c|c|c|c|c|c|c|c|c|}
\hline & \multirow{2}{*}{ MEREK } & \multicolumn{7}{|c|}{ SUSU YANG DI KONSUMSI } & \multirow{3}{*}{$\begin{array}{c}\text { Total } \\
11 \\
\end{array}$} \\
\hline & & \multirow{2}{*}{$\begin{array}{c}\text { Anlene } \\
5 \\
\end{array}$} & \multirow{2}{*}{$\begin{array}{c}\text { Bendera } \\
3 \\
\end{array}$} & \multirow{2}{*}{$\begin{array}{c}\text { Dancow } \\
2 \\
\end{array}$} & \multirow{2}{*}{$\begin{array}{c}\text { Indomilk } \\
1 \\
\end{array}$} & \multirow{2}{*}{$\begin{array}{c}\begin{array}{c}\text { Sustagen } \\
\text { HP }\end{array} \\
0\end{array}$} & \multirow{2}{*}{$\begin{array}{c}\text { Lainnya } \\
0 \\
\end{array}$} & \multirow{2}{*}{$\begin{array}{c}\begin{array}{c}\text { Tidak } \\
\text { Memilih }\end{array} \\
0 \\
\end{array}$} & \\
\hline \multirow{7}{*}{ 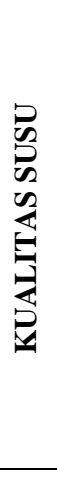 } & Anlene & & & & & & & & \\
\hline & Bendera & 0 & 8 & 0 & 0 & 0 & 0 & 0 & 8 \\
\hline & Dancow & $\mathbf{0}$ & 2 & 40 & 5 & 1 & 4 & $\mathbf{0}$ & 52 \\
\hline & Pediasure & 5 & 0 & 1 & 0 & 0 & 0 & 0 & 6 \\
\hline & $\begin{array}{l}\text { Sustagen } \\
\text { HP }\end{array}$ & 0 & 7 & 11 & 2 & 11 & 3 & 0 & 34 \\
\hline & Lainnya & 0 & 5 & 8 & 3 & 0 & 7 & 1 & 24 \\
\hline & $\begin{array}{l}\text { Tidak } \\
\text { Memilih }\end{array}$ & 0 & 0 & 1 & 0 & 0 & 0 & 5 & 6 \\
\hline & Total & 10 & 25 & 63 & 11 & 12 & 14 & 6 & 141 \\
\hline
\end{tabular}

Keterangan : $\quad \vee$ Tidak Memilih (Kosong)

- Kualitas Lainnya (Andec, Bear Brand, Bebelac, Calcimex, Cap Bunga, Cap Enak, Cap Nona, Carnation, Child Kid, Dutch Lady, Enercal, Enfapro, Enfamil, Femavit, Indomilk, Lactogen, Lactona, Milkmaid, Milo, Mony, Morimoya, Nutricia, Nutrilon, Nutrima, Ovaltine, Prenagen, Procal, Prolene, Promil, S 26, SGM, Stefit, Tropicana Slim, Ultra, WRP)

- Konsumsi Lainnya (Andec, Bear Brand, Bebelac, Calcimex, Cap Bunga, Cap Enak, Cap Nona, Carnation, Child Kid, Dutch Lady, Enercal, Enfapro, Enfamil, Femavit, Lactogen, Lactona, Milkmaid, Milo, Mony, Morimoya, Nutricia, Nutrilon, Nutrima, Ovaltine, Pediasure, Prenagen, Procal, Prolene, Promil, S 26, SGM, Stefit, Tropicana Slim, Ultra, WRP)

- Chi-Square $=279,233$ dan $\mathrm{DF}=36$

Hasil Chi-Square dari perhitungan ialah 279,233 sedangkan nilai Chi-Square tabel ialah 50,998 pada taraf nyata 5\%, jadi adanya hubungan yang signifikan antara persepsi kualitas dengan persepsi susu yang sering dikonsumsi. Dapat dikatakan bahwa konsumen mempunyai persepsi bahwa susu yang paling berkualitas mempengaruhi pola konsumsi susu atau mempengaruhi merek susu yang dipakai, hal ini bisa disebabkan oleh adanya persepsi konsumen bahwa kualitas susu merupakan salah satu faktor yang menentukan pembelian atau pemakaian. 


\section{Analisis Hubungan Antara Persepsi Harga Merek Susu Dengan Merek Susu yang Dikonsumsi}

Tabulasi hubungan antara persepsi harga dengan susu yang dikonsumsi oleh konsumen dapat dilihat dari tabel 11. Pada tabel tersebut dapat diinterpretasikan bahwa dari 38 responden yang menyatakan bahwa susu Sustagen HP sebagai susu yang paling mahal harganya tetapi hanya 6 responden $(15,79 \%)$ yang berpersepsi bahwa susu yang paling mahal mencerminkan bahwa susu itu cocok dan bermanfaat untuk dipakai, sedangkan 17 responden (44,74\%) memilih susu Dancow, 9 responden $(23,68 \%)$ memilih susu Bendera, 3 responden $(7,89)$ memilih Indomilk, 1 responden $(2,63 \%)$ memilih susu Anlene sedangkan 2 responden $(5,26 \%)$ memilih susu lainnya.

Tabel 11. Hubungan harga merek susu dengan Merek susu yang dikonsumsi

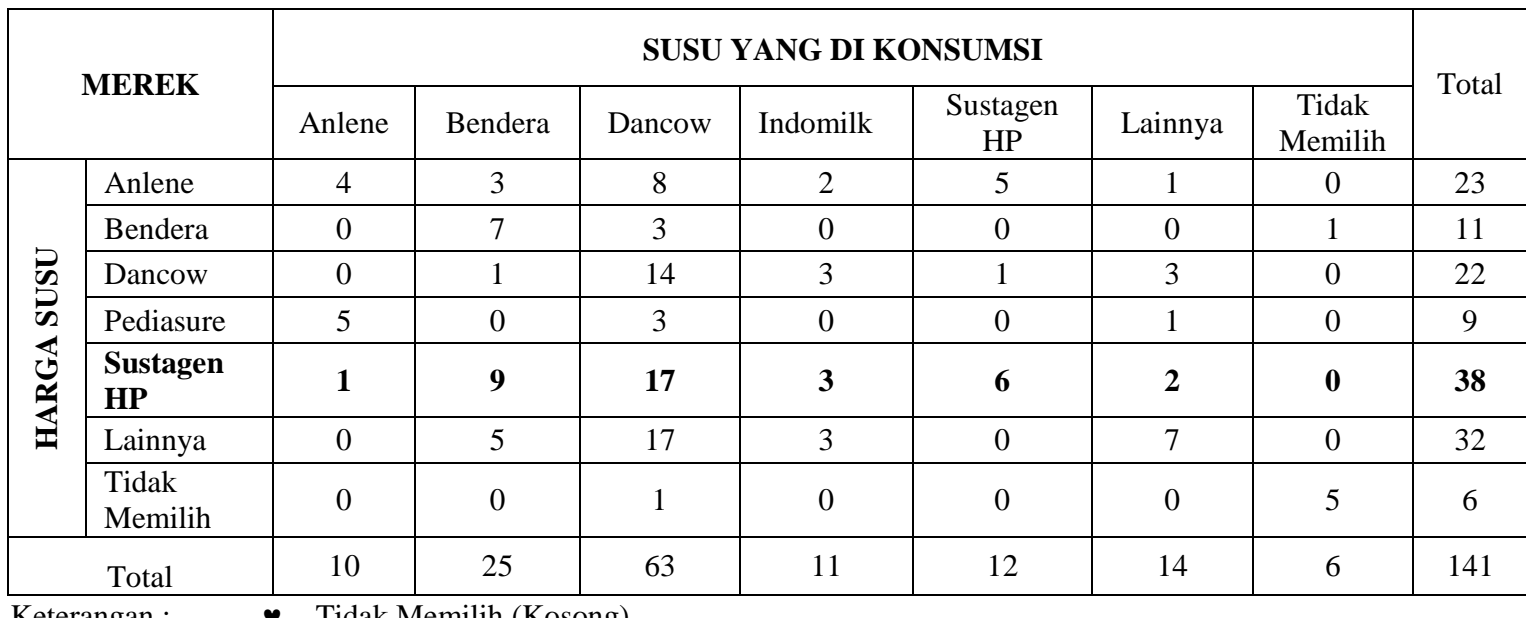

Keterangan :

- Harga Lainnya (Andec, Bear Brand, Bebelac, Calcimex, Cap Bunga, Cap Enak, Cap Nona, Carnation, Child Kid, Dutch Lady, Enercal, Enfapro, Enfamil, Femavit, Indomilk, Lactogen, Lactona, Milkmaid, Milo, Mony, Morimoya, Nutricia, Nutrilon, Nutrima, Ovaltine, Prenagen, Procal, Prolene, Promil, S 26, SGM, Stefit, Tropicana Slim, Ultra, WRP)

- Konsumsi Lainnya (Andec, Bear Brand, Bebelac, Calcimex, Cap Bunga, Cap Enak, Cap Nona, Carnation, Child Kid, Dutch Lady, Enercal, Enfapro, Enfamil, Femavit, Lactogen, Lactona, Milkmaid, Milo, Mony, Morimoya, Nutricia, Nutrilon, Nutrima, Ovaltine, Pediasure, Prenagen, Procal, Prolene, Promil, S 26, SGM, Stefit, Tropicana Slim, Ultra, WRP)

- Chi-Square $=180,969$ dan $\mathrm{DF}=36$

Hasil nilai Chi-Square dari perhitungan ialah 180,969 sedangkan nilai Chi-Square tabel ialah 50,998 pada taraf nyata 5\%, jadi adanya hubungan yang signifikan antara 
persepsi harga merek susu dengan persepsi susu yang sering dikonsumsi. Dapat dikatakan bahwa konsumen mempunyai persepsi bahwa susu yang paling mahal mempengaruhi pola konsumsi susu atau mempengaruhi merek susu yang dipakai, Dapat dikatakan bahwa konsumen mempunyai persepsi bahwa susu yang paling mahal dapat dapat bermanfaat bagi konsumen dan akhirnya dapat mempengaruhi pola konsumsi susu atau mempengaruhi merek susu yang dipakai.

Dari keterangan di atas dapat disimpulkan bahwa hanya 6 responden yang memilih dan memakai susu Sustagen HP, sedangkan sebanyak 32 responden memakai susu yang lainnya. Hal tersebut dapat dipahami bahwa harga yang tinggi tidak mencerminkan bahwa susu tersebut cocok untuk dipakai oleh responden. Apabila memperhatikan data dari responden, ada kecenderungan konsumen mengalihkan pembelian sutu produk yang mahal dan berusaha untuk membeli produk yang harganya relatif lebih murah, karena daya beli konsumen yang rata-rata rendah akibat adanya krisis ekonomi yang terjadi sekarang ini dan konsumen berusaha mencari susu yang benarbenar dirasakan sangat bermanfaat untuk dikonsumsi.

\section{Analisis Hubungan antara pendapatan dengan rata-rata pengeluaran untuk membeli susu setiap bulan}

Tabulasi hubungan antara persepsi harga dengan susu yang dikonsumsi oleh konsumen dapat dilihat dari Tabel 12 dibawah ini .

Tabel 12. Hubungan pendapatan dengan rata-rata pengeluaran untuk membeli susu setiap bulan

\begin{tabular}{|c|c|c|c|c|c|}
\hline \multirow{2}{*}{\multicolumn{2}{|c|}{ PENDAPATAN }} & \multicolumn{3}{|c|}{ PENGELUARAN } & \multirow{2}{*}{ TOTAL } \\
\hline & & $0-45000$ & $45001-145000$ & $1450001-1000000$ & \\
\hline \multirow{4}{*}{  } & -2950000 & 1 & 1 & 1 & 3 \\
\hline & $2950001-5000000$ & 27 & 35 & 28 & 90 \\
\hline & $5000001-27000000$ & 16 & 13 & 19 & 48 \\
\hline & TOTAL & 44 & 49 & 48 & 141 \\
\hline
\end{tabular}


Hasil nilai Chi-Square dari perhitungan ialah 2,304 sedangkan nilai Chi-Square tabel ialah 9,488 pada taraf nyata 5\%, artinya bahwa tidak adanya hubungan antara pendapatan dengan pengeluaran untuk membeli susu setiap bulan pada tingkat kepercayaan 95\%. Pada Tabel 12. di atas dapat diinterpretasikan bahwa dari 90 responden yang menyatakan bahwa dengan pendapatan yang berkisar antara Rp. 2950001 sampai Rp. 5.000.000 hanya 27 responden yang pengeluaran untuk membeli susu ratarata per bulan adalah Rp. 0 sampai Rp. 45000, 35 responden yang pengeluaran untuk membeli susu rata-rata per bulan adalah Rp. 45.001 sampai Rp.145.000, 28 responden yang pengeluaran untuk membeli susu rata-rata per bulan adalah Rp. 145.001 sampai Rp. 1.000.000.

\section{Hubungan antar variabel dengan menggunakan uji Kontingensi}

Untuk mengukur kekuatan hubungan antar variabel, maka salah satu alat untuk melakukan penelitian adalah dengan menggunakan analisis kontingensi. Dengan menggunakan uji kontingensi, akan didapatkan hubungan antarvariabel yang akan diuji.

Tabel 13. Uji Kontingensi dengan menggunakan taraf nyata 5\%

\begin{tabular}{|c|c|c|c|c|c|}
\hline Analisis & Chi - Square & Df & $\begin{array}{c}\text { Chi-Square Tabel } \\
\boldsymbol{\alpha}=\mathbf{5 \%}\end{array}$ & Kontingensi & Hasil \\
\hline 1 & 139,888 & 36 & 50,998 & 0,70571 & $\begin{array}{c}\text { Hubungannya } \\
\text { Sangat kuat }\end{array}$ \\
\hline 2 & 134,682 & 36 & 50,998 & 0,69896 & $\begin{array}{c}\text { Hubungannya } \\
\text { Sangat kuat }\end{array}$ \\
\hline 3 & 204,075 & 36 & 50,998 & 0,76902 & $\begin{array}{c}\text { Hubungannya } \\
\text { Sangat kuat }\end{array}$ \\
\hline 4 & 384,145 & 36 & 50,998 & 0,85528 & $\begin{array}{c}\text { Hubungannya } \\
\text { Sangat kuat }\end{array}$ \\
\hline 5 & 279,233 & 36 & 50,998 & 0,81515 & $\begin{array}{c}\text { Hubungannya } \\
\text { Sangat kuat }\end{array}$ \\
\hline 6 & 180,969 & 36 & 50,998 & 0,74971 & $\begin{array}{c}\text { Hubungannya } \\
\text { Sangat kuat }\end{array}$ \\
\hline 7 & 2,034 & 4 & 9,488 & 0,11925 & $\begin{array}{c}\text { Hubungannya } \\
\text { Tidak begitu kuat }\end{array}$ \\
\hline
\end{tabular}

Keterangan :

Hubungan antara persepsi Popularitas dengan kualitas
Hubungan antara persepsi Popularitas dengan harga
Hubungan antara persepsi popularitas dengan konsumsi
Hubungan antara persepsi kualitas dengan harga
Hubungan antara persepsi kualitas dengan konsumsi
Hubungan antara persepsi harga dengan konsumsi
Hubungan antara pendapatan dengan rata-rata pengeluaran

Pada tabel di atas dapat terlihat bahwa hampir semua dugaan antar variabel saling erat dan berpengaruh kuat secara signifikan pada taraf nyata 5\%, tetapi hanya pada uji hubungan antara pendapatan dengan rata-rata pengeluaran untuk membeli susu setiap 
bulan dimana hubungan kedua variabel tersebut kurang begitu kuat/tidak erat hubungannya atau tidak saling berpengaruh secara signifikan.

Tabel 14. Uji Kontingensi dengan menggunakan taraf nyata $10 \%$

\begin{tabular}{|c|c|c|c|c|c|}
\hline Analisis & Chi - Square & Df & $\begin{array}{c}\text { Chi-Square Tabel } \\
\boldsymbol{\alpha}=\mathbf{1 0 \%}\end{array}$ & Kontingensi & Hasil \\
\hline 1 & 139,888 & 36 & 47,212 & 0,70571 & $\begin{array}{c}\text { Hubungannya } \\
\text { Sangat kuat }\end{array}$ \\
\hline 2 & 134,682 & 36 & 47,212 & 0,69896 & $\begin{array}{c}\text { Hubungannya } \\
\text { Sangat kuat }\end{array}$ \\
\hline 3 & 204,075 & 36 & 47,212 & 0,76902 & $\begin{array}{c}\text { Hubungannya } \\
\text { Sangat kuat }\end{array}$ \\
\hline 4 & 384,145 & 36 & 47,212 & 0,85528 & $\begin{array}{c}\text { Hubungannya } \\
\text { Sangat kuat }\end{array}$ \\
\hline 5 & 279,233 & 36 & 47,212 & 0,81515 & $\begin{array}{c}\text { Hubungannya } \\
\text { Sangat kuat }\end{array}$ \\
\hline 6 & 180,969 & 36 & 47,212 & 0,74971 & $\begin{array}{c}\text { Hubungannya } \\
\text { Sangat kuat }\end{array}$ \\
\hline 7 & 2,034 & 4 & 7,779 & 0,11925 & $\begin{array}{c}\text { Hubungannya } \\
\text { Tidak kuat }\end{array}$ \\
\hline
\end{tabular}

Keterangan :

Hubungan antara persepsi Popularitas dengan kualitas
Hubungan antara persepsi Popularitas dengan harga
Hubungan antara persepsi popularitas dengan konsumsi
Hubungan antara persepsi kualitas dengan harga
Hubungan antara persepsi kualitas dengan konsumsi
Hubungan antara persepsi harga dengan konsumsi
Hubungan antara pendapatan dengan rata-rata pengeluaran

Pada tabel 14 dapat terlihat bahwa hampir semua kesimpulan yang diperlihatkan sama seperti kesimpulan pada tabel 13. Dimana dugaan antar variabel saling erat dan berpengaruh kuat secara signifikan pada taraf nyata $10 \%$, tetapi hanya pada uji hubungan antara pendapatan dengan rata-rata pengeluaran untuk membeli susu setiap bulan dimana hubungan kedua variabel tersebut tidak kuat/tidak erat hubungannya atau tidak saling berpengaruh secara signifikan, dan kasus mempunyai kesamaan seperti uji kontingensi pada taraf nyata $5 \%$.

Tabel 15. Uji Kontingensi dengan menggunakan taraf nyata $1 \%$

\begin{tabular}{|c|c|c|c|c|c|}
\hline Analisis & Chi-Square & Df & $\begin{array}{c}\text { Chi-Square Tabel } \\
\boldsymbol{\alpha = 1 \%}\end{array}$ & Kontingensi & Hasil \\
\hline 1 & 139,888 & 36 & 9,210 & 0,70571 & $\begin{array}{c}\text { Hubungannya } \\
\text { Sangat kuat }\end{array}$ \\
\hline 2 & 134,682 & 36 & 9,210 & 0,69896 & $\begin{array}{c}\text { Hubungannya } \\
\text { Sangat kuat }\end{array}$ \\
\hline 3 & 204,075 & 36 & 9,210 & 0,76902 & $\begin{array}{c}\text { Hubungannya } \\
\text { Sangat kuat }\end{array}$ \\
\hline 4 & 384,145 & 36 & 9,210 & 0,85528 & $\begin{array}{c}\text { Hubungannya } \\
\text { Sangat kuat }\end{array}$ \\
\hline 5 & 279,233 & 36 & 9,210 & 0,81515 & $\begin{array}{c}\text { Hubungannya } \\
\text { Sangat kuat }\end{array}$ \\
\hline 6 & 180,969 & 36 & 9,210 & 0,74971 & Hubungannya \\
\hline
\end{tabular}




\begin{tabular}{|c|c|c|c|c|c|}
\hline & & & & & Sangat kuat \\
\hline 7 & 2,034 & 4 & 13,277 & 0,11925 & $\begin{array}{c}\text { Hubungannya } \\
\text { Sangat Tidak kuat }\end{array}$ \\
\hline
\end{tabular}

Keterangan :
Hubungan antara persepsi Popularitas dengan kualitas
Hubungan antara persepsi Popularitas dengan harga
Hubungan antara persepsi popularitas dengan konsumsi
Hubungan antara persepsi kualitas dengan harga
Hubungan antara persepsi kualitas dengan konsumsi
Hubungan antara persepsi harga dengan konsumsi
Hubungan antara pendapatan dengan rata-rata pengeluaran

Pada Tabel 15 dapat terlihat bahwa hampir semua dugaan antar variabel saling erat dan berpengaruh kuat secara signifikan pada taraf nyata $1 \%$, tetapi kasusnya sama dengan uji kontingensi pada taraf nyata 5\% dan 10\% dimana hanya pada uji hubungan antara pendapatan dengan rata-rata pengeluaran untuk membeli susu setiap bulan dimana hubungan kedua variabel tersebut tidak kuat/tidak erat hubungannya atau tidak saling berpengaruh secara signifikan, dan kasus mempunyai kesamaan seperti uji kontingensi pada taraf nyata $5 \%$ dan $10 \%$.

\section{SIMPULAN}

Pendekatan statistik nonparametrik yang digunalan dalam penelitian ini maka terdapat 41 merek susu yang menjadi pilihan responden dengan tingkat popularitas, yaitu adalah : (1) Dancow dengan jumlah responden 72 (52,94 \%); (2) Bendera dengan jumlah responden 44 (32,59\%); (3) Indomilk dengan jumlah responden 36 (26,86\%); (4) Sustagen HP dengan jumlah responden $18(14,40 \%)$ dan Anlene dengan jumlah responden $21(17,95 \%)$

Sebagian besar responden memilih susu Dancow di sebabkan oleh beberapa hal, antara lain kualitas content dari tingkat kandungan gizi dan vitamin serta tingkat kepercayaan konsumen akan kebersihan dan keorisinilan kandungan isi sejak dari proses sampai pendistribusian ditambah dengan jaminan dari produsen Nestle yang telah terkenal diseluruh dunia dengan jaminan mutu dan kualitasnya, ditambah dengan data responden tentang pemilihan susu berkualitas terlihat bahwa 52 responden $(38,52 \%)$ menyatakan bahwa susu Dancow mempunyai kualitas paling baik diantara yang lain.

Dalam strategi harga yang dikaitkan dengan produk, terlihat bahwa harga susu dancow berbanding dengan produk dimata konsumen paling sesuai. Terdapat tingkat kepuasan tersendiri di dalam benek konsumen baik dalam bentuk pengalaman maupun 
dari media informasi lainnya. Sementara itu, untuk produk susu sebenarnya yang paling penting adalah penanaman tingkat kepercayaan dalam benak konsumen terhadap produk karena pada dasarnya semua produk susu mempunyai deferensiasi produk yang kecil dari kandungan produknya. Selain itu, yang paling signifikan membedakan produk susu berdasarkan segmentasi seperti susu untuk ibu hamil, untuk ibu menyusui, untuk balita, untuk bayi dan sebagainya. Untuk produk mungkin hanya tambahan beberapa vitamin tertentu seperti tambahan kalsium untuk susu manula dan seterusnya. Untuk produk yang membedakan hanyalah dibedakan kepada susu cair dan susu bubuk, hal tersebut hanyalah lebih kepada penggunaannya seperti susu cair biasanya lebih campuran es teler, kue dan sebagainya selain murni untuk diminum. Sedangkan susu bubuk biasanya oleh konsumen murni untuk diminum. Untuk survei yang dilakukan lebih kepada susu bubuk.

Penanaman tingkat kepercayaan dalam benak konsumen untuk produk susu lebih kepada promosi. Dari data SWA dari tahun 1999 s/d 2001 terlihat bahwa untuk produk yang diloyalitaskan dan populer dimata konsumen tahun 1999 adalah Dancow, akan tetapi di tahun 2000 Bendera menjadi yang populer dan ditahun 2001 awal, kembali Dancow menjadi peringkat pertama. Dari paparan SWA dapat diambil kesimpulan dari penanaman image melalui promosi ditahun 2001 awal, Dancow memegang peringkat pertama dengan top of mind dengan 48,9\% didalam benak konsumen dari keseluruhan produk. Bila dibandingkan dengan produk susu lainnya hal, sangat jauh persentasi top of mind. Dengan image "Mamah tambah tinggi" yang dikeluarkan dari mulut seorang anak balita mempengaruhi konsumen ditambah dengan gencarnya iklan di media terutama televisi.

Kelemahan studi ini adalah variasi data tentang susu yang dipilih responden terlalu besar dan banyak responden yang tidak mengisi kuisioner dan banyak juga yang mengisi tidak sesuai yang diharapkan misalnya mengisi kuisioner bukan merek susu, sehingga sulit di dalam melakukan pengolahan data yang mengakibatkan kemungkinan terjadinya bias dalam pengolahan data terutama untuk uji Chi-Square. Dalam pengolahan dilakukan pengelompokan kedalam jenis susu lainnya yang terdiri dari banyak merek susu. Oleh karena itu, rencana variabel yang diteliti harus lebih teliti lagi agar uji hubungan antar variabel dan koefisien kontingensi-nya dapat memenuhi syarat untuk uji tersebut. 


\section{REFERENSI}

A. Lind, Douglas, Wiliam G. Marchal, dan Samuel A. Wathen. (2005). "Statistical Techniques in Bussiness \& Economics". New York: Mc Graw Hill.

Engel. JF, Roger D. Blackwell. Paul W. Miniard, (1994). "Perilaku konsumen". Terjemahan Bina Rupa Aksara. Jakarta

Intisari, susu minuman penjajah bikin sehat, november 2000

Kompas, mungkinkah susu menjadi primadona, 21 juli 1997

Mowen, C.J.(1997). “Consumer Behaviour”. Prentice Hall.Inc. New Jersey

Porter, M. (1993). “Strategi Bersaing: Teknik Menganalisis Industri Dan Pesaing”. Erlangga. Jakarta.

Kotler, P. (1991). "Manajemen Pemasaran : Analisis, Perencanaan dan Pengendalian. Jilid 2". Erlangga. Jakarta

Sutisna, (2001) "Perilaku Konsumen dan Komukasi Pemasaran", CV. Rosda Karya Bandung, 2001

Umar, Husein (2000). "Riset Pemasaran dan Perilaku Konsumen". Gramedia Pustaka Jakarta 2000 